\title{
اشكاليات المناهج النقدية الغربية وأثرها فى النقد العربى المعاصر -المنهج التكاملى العربى نموذجا-
}

$$
\begin{aligned}
& \text { د. سماح خميس مسعودعبدالرازق } \\
& \text { مدرس الدراما والنقد المسرحى فعي } \\
& \text { قسم الدراسات المسرحية } \\
& \text { كلية الآداب جامعة الاسكندرية }
\end{aligned}
$$

ملخص البحث باللغ

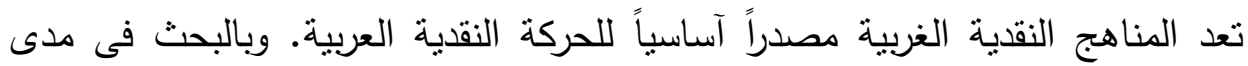

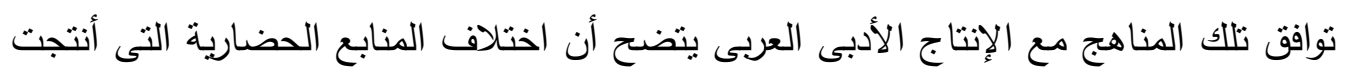

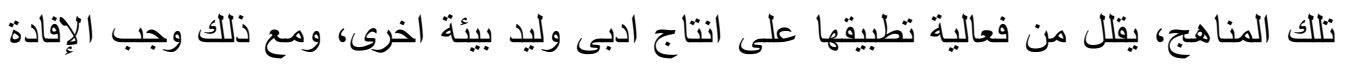

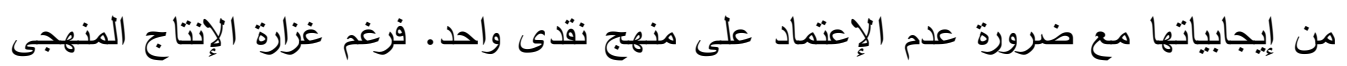

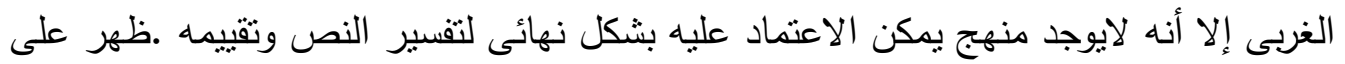

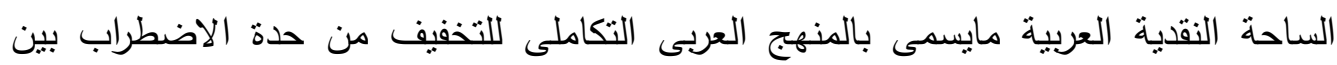

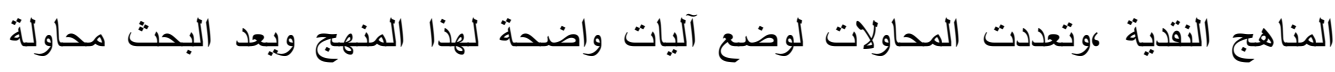

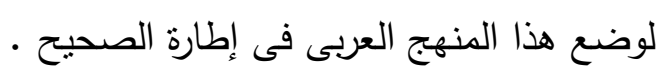

\section{The problems of the western critical subjects and its influence on the Arab modern critic (for example the complete Arab subject)}

western critical subjects are considered as a main guide to the Arab critical movement and in looking for matching between the Arab artistic production, we find that the difference between western civilization sources which produced those subjects don't match with the Arab artistic products.so we have to take the positives and should not depend on one critical subject, because there is no subject which can explain the artistic text. So Arab critics produced the complete Arab subject, and this research is an experiment to put the Arab subjects in the right way. 


\section{مقدمة:}

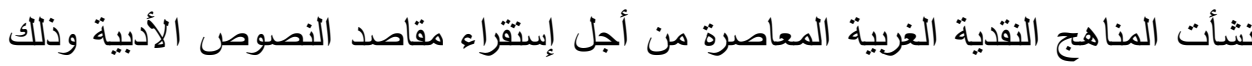

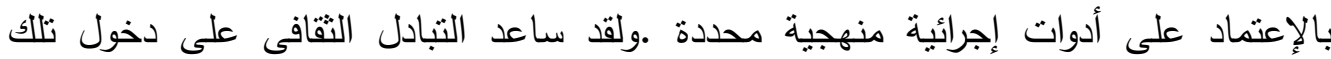
المناهج الغربية إلى حقل النقد الأدبى العربى حتى أصبحت التبعة التبعية التنظيرية للمناهج النقدية

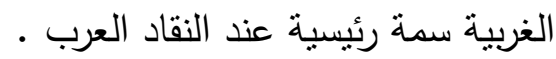

\section{وتبرز إثكالية البحث فى عدة أسئلة هي:}

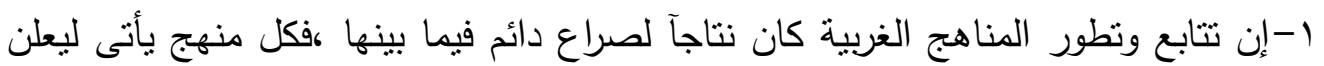

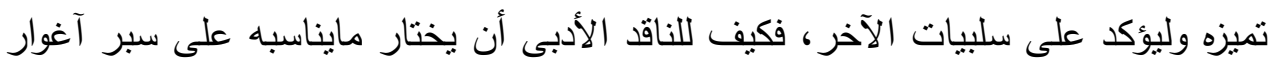

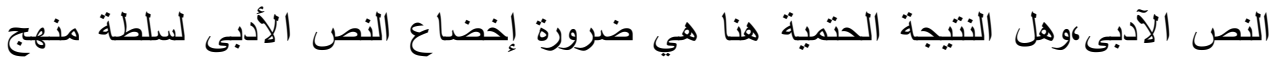

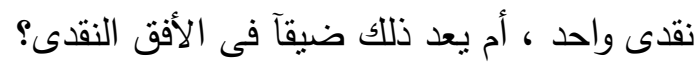

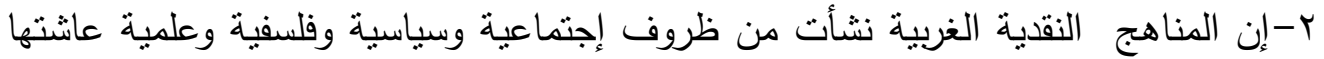

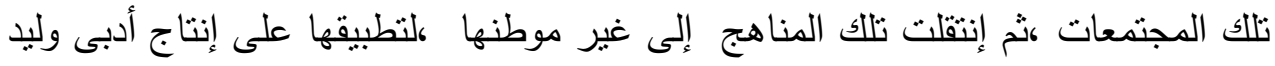
لبيئة مختلفة. فهل يمكن إخضاع الخطاب الآدبى العربى لسلطة أداة نقدية مغايرة مورفولوجيآ ؟

ب-هل المنهج التكاملى العربى الذى نشأ كمحاولة لتجميع إيجابيات المناهج التراثية العربية

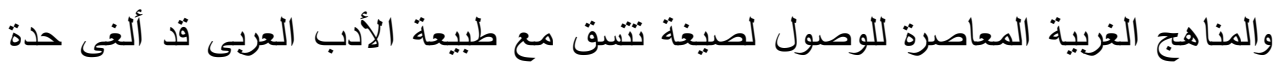
الاضطرابات والصراعات النقدية ؟

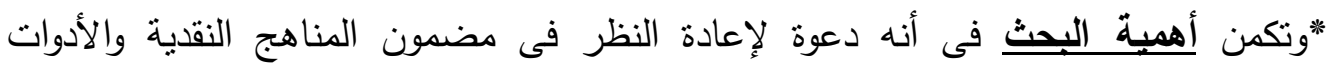

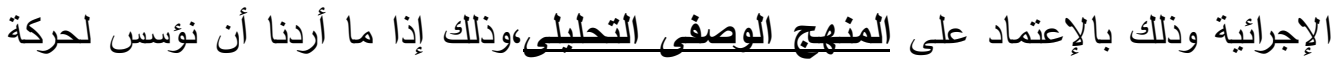
نقدية عربية حقبقية .

المبحث الأول ...تبعية النص المسرحى العربى للمناهج النقدية الغربية :

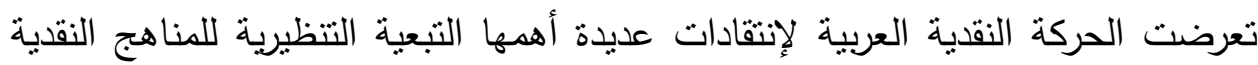

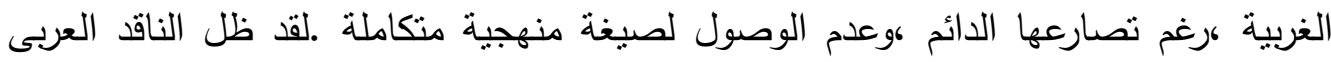

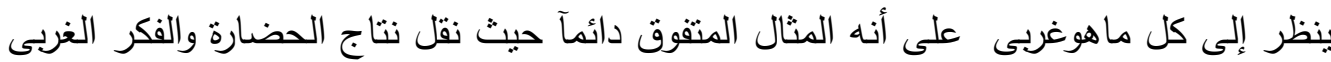
على واقعه الأدبى المغاير، مما قد يضعف الخطاب النقدى العربى وقدرته على الإفادة بشكل

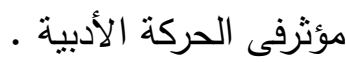

-المحور الأول ....خضوع النص المسرحى لسلطة أداة نقاية واحدة.

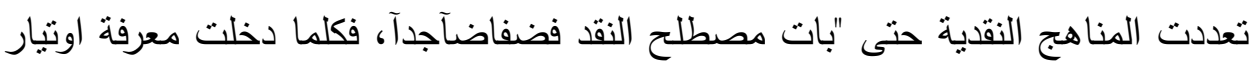

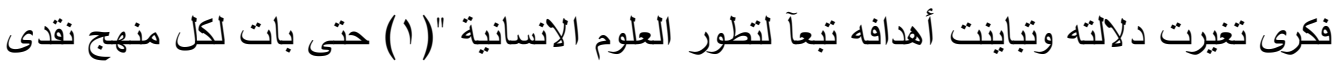
جوانب إيجابية وأخرى سلبية ـ وتتحصر المناهج النقدية الغربية فى مسارين: 
الأول :المناهج النقدية السياقية : (والتى تدرس النص من الخارج وأبرزها المنهج التاريخى والإجتماعى والإنطباعى والإسطوري والنفسى ).

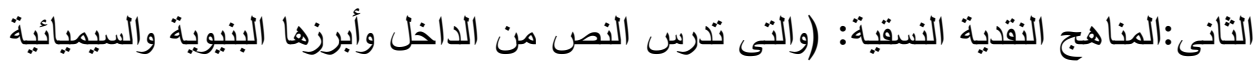
والتفككية ونظرية التلقى).

"ويعدالمنهج التاريخى أول المناهج النقدية ظهورآ فى العصر الحديث ،لقد تبلور المنهج

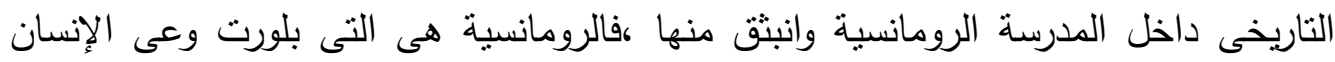

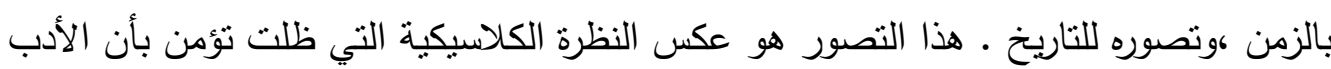

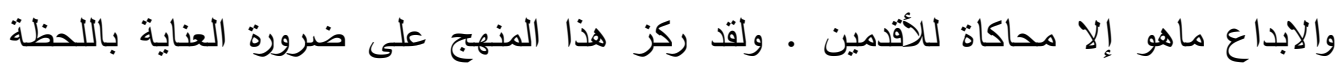

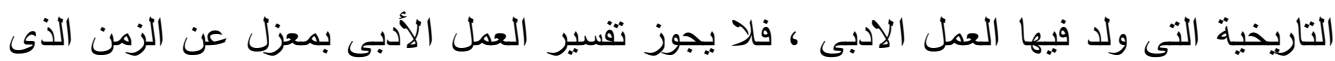

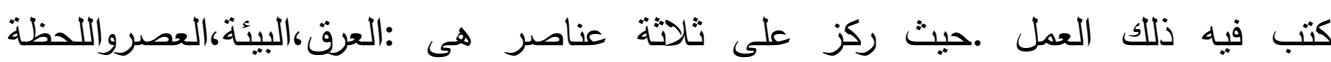

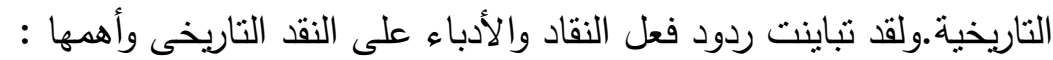

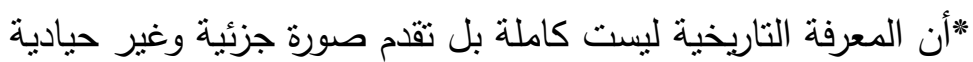

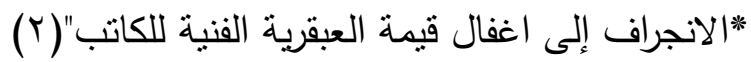

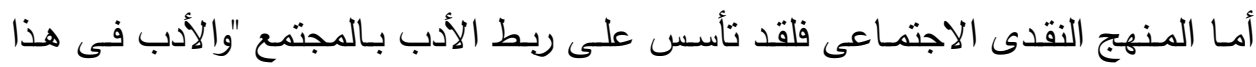

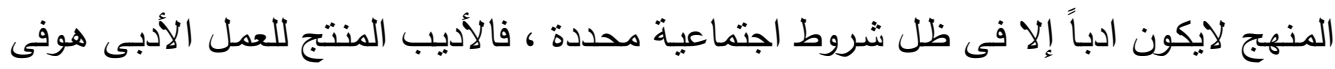

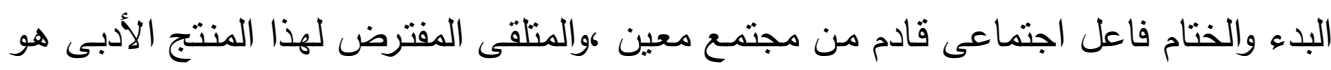

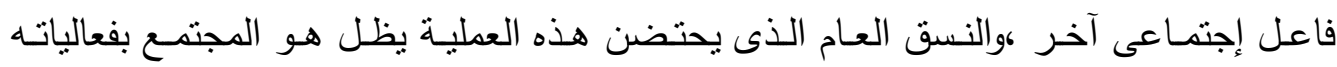

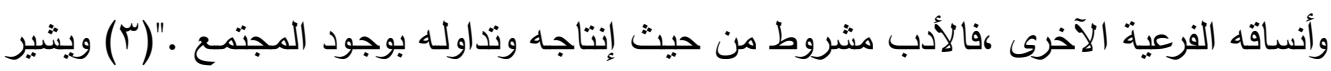

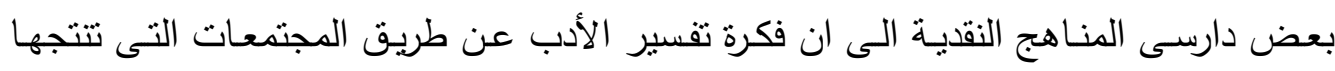

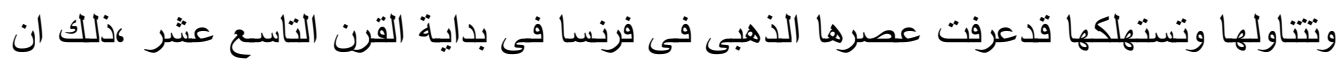

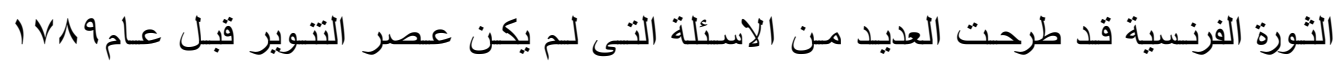

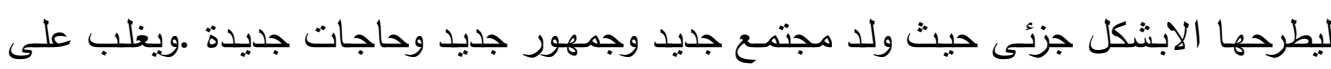

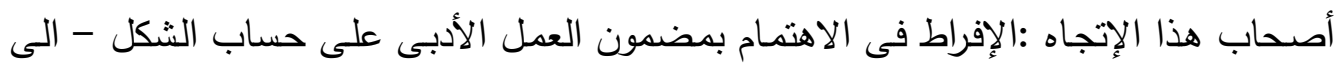

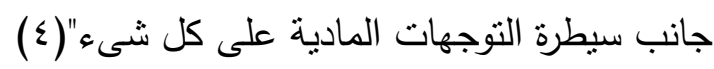
ظلت عمليات الإبداع النقدى فى تتامى وتعدد مستمر حيث ذهي ذهب البعان البعض إلى ان النقد

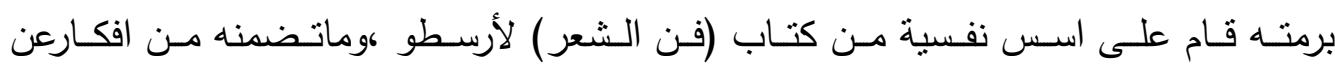

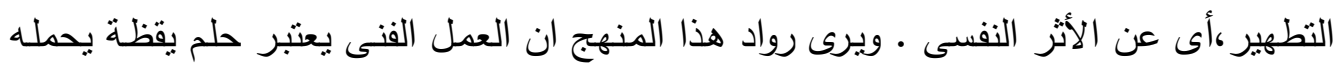

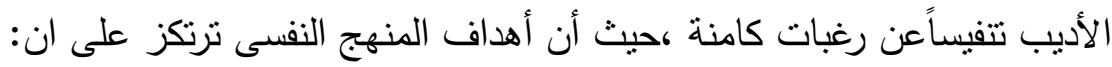

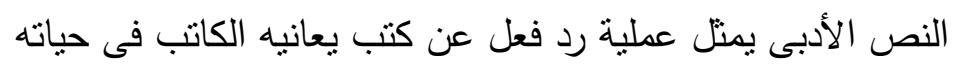

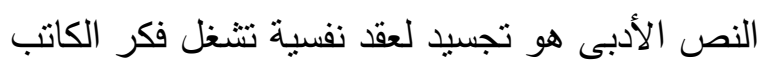

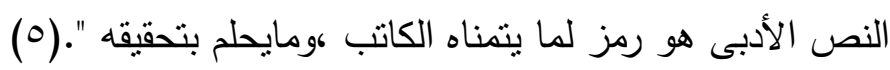


ولقد استمد هذا المنهج عناصره وأدواته من نظريات فرويد فى علم نفس اما عن جوانب

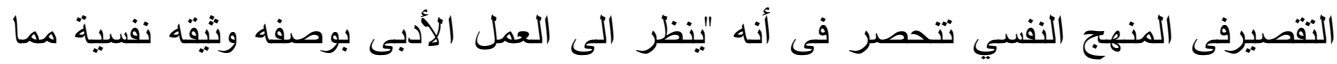

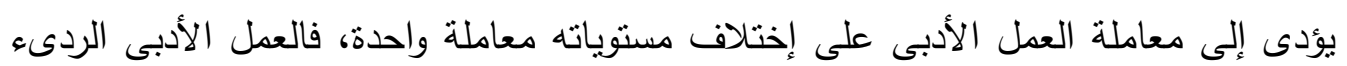

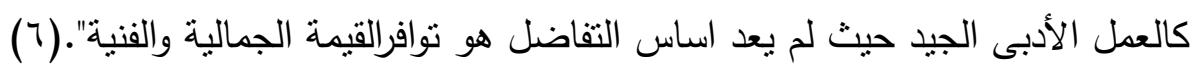
وبظهور الأنثربولوجيا كنظرية علمية والتي اهتمت بتتبع بدايات الجنس البشرى وموروثاته

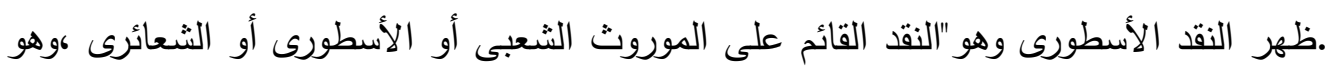

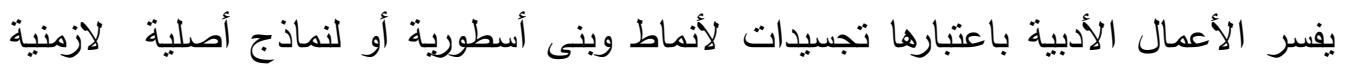

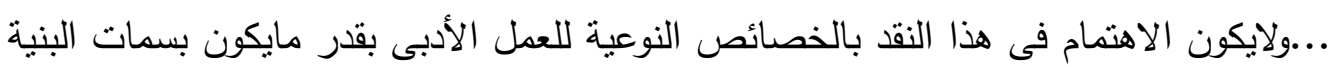

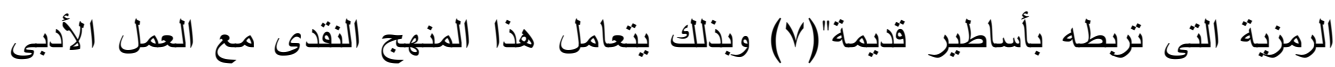

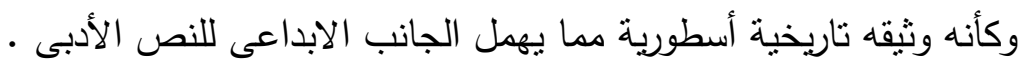

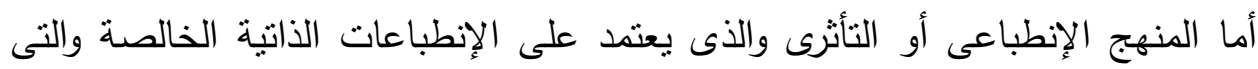

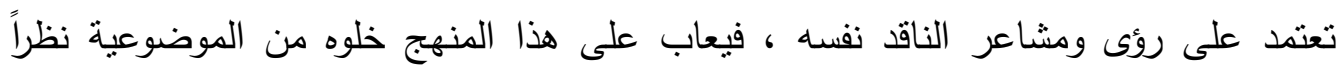

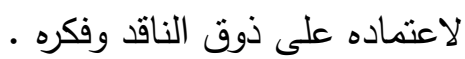
تعددت المناهج النقدية السياقية - والتى عرض البحث أبرذ أبرزها - من أجل تفسير وتقويم الأدب وتفسيره ،ومما سبق بلاحظ أن : - القراءة النقدية السياقية نتطلق من نطور النظريات العلمية وتوجهات أيدولوجية ارتبطت

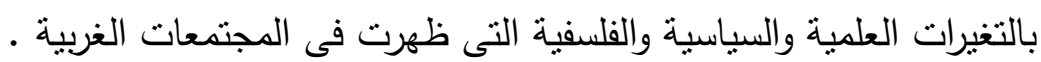

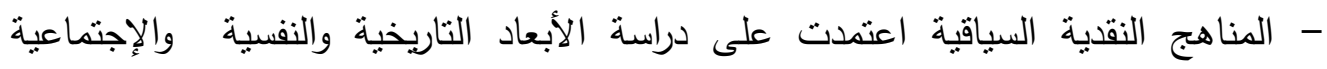

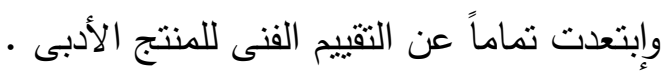

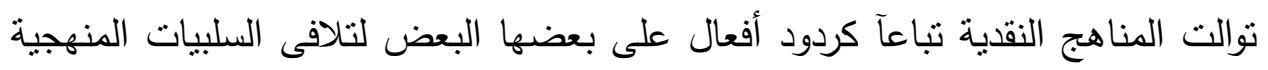

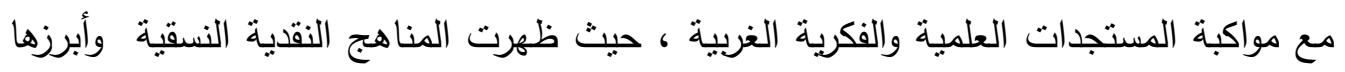

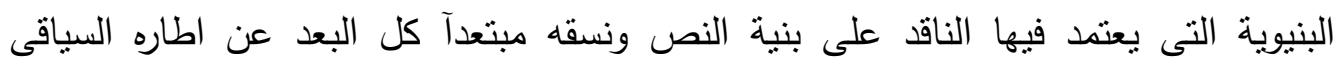

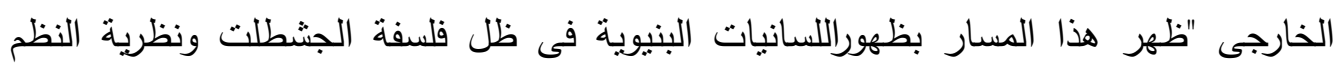

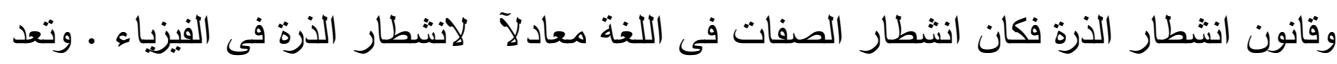

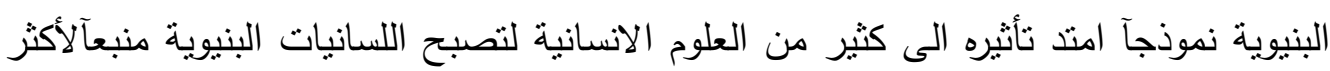

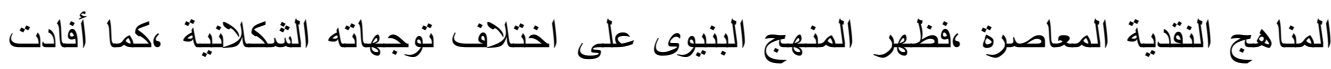

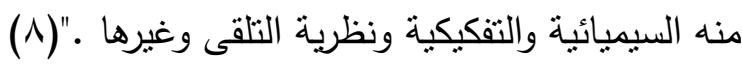

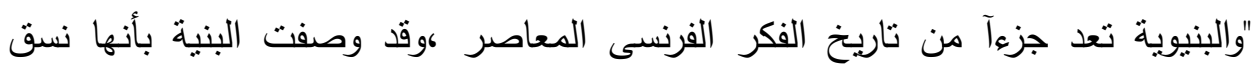

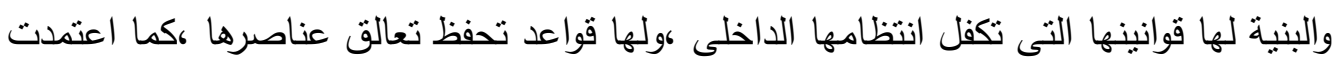

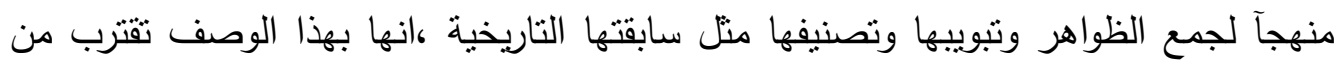


العلوم الصورية كبحيث انها لاتهتم بالمعنى انها تدرس فقط العلاقات القائمة بين عناصر أجزاء

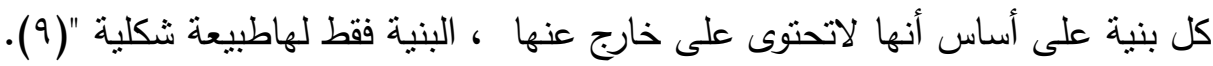

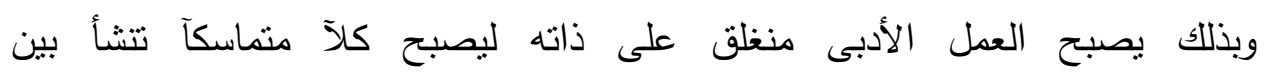

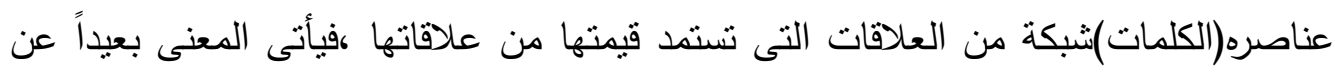

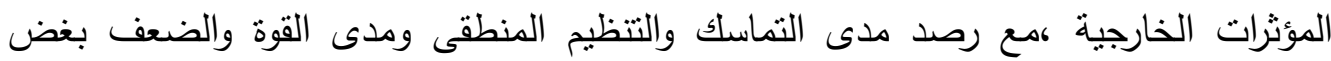

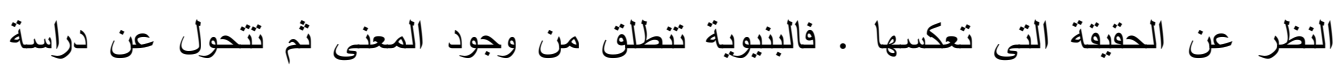

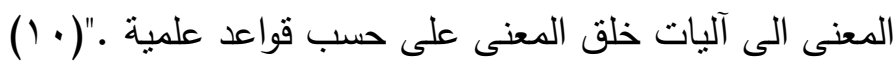

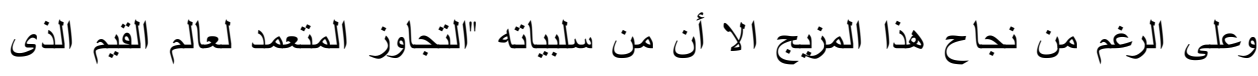

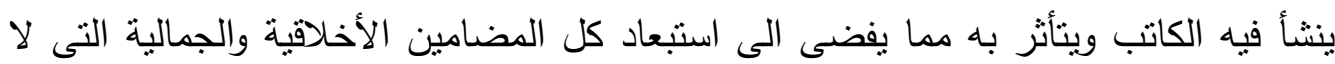

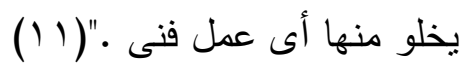
وانطلاقآمن البنيوية ذهب النقاد فى رحلة بحث أنتجت العديد من المناهج النقدية .ولقد بدأ

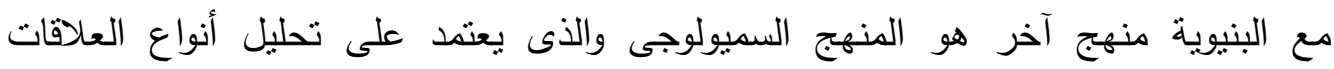

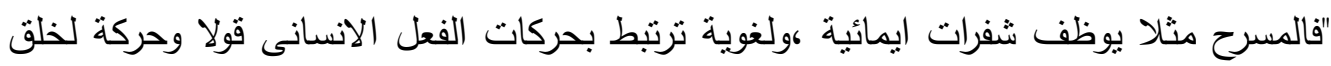

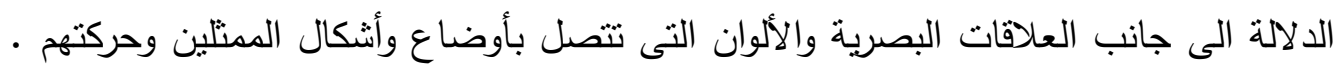

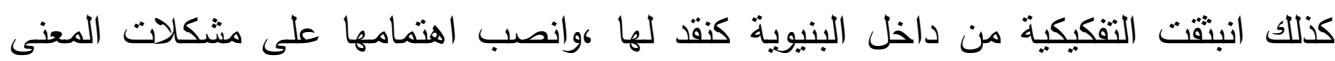

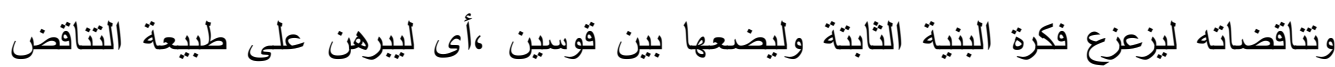

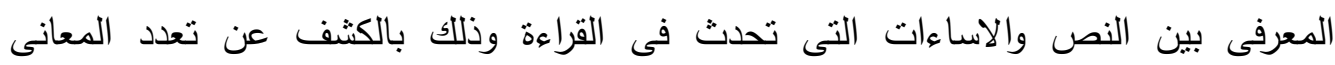

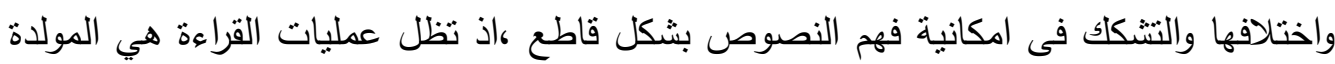

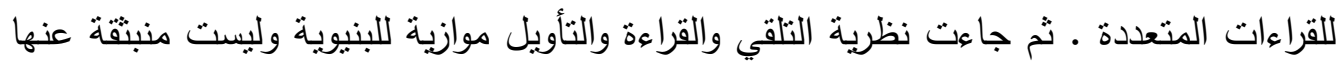

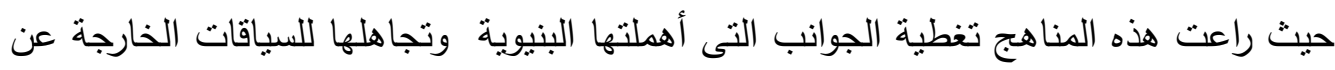

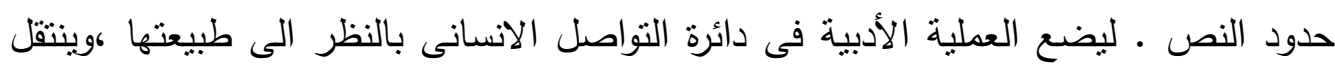

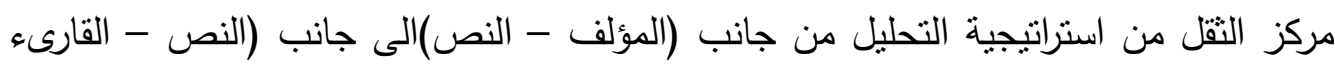

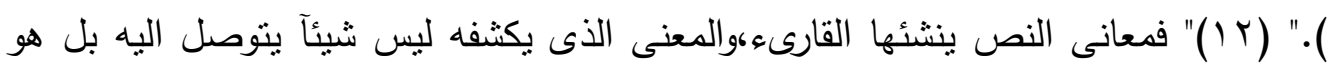

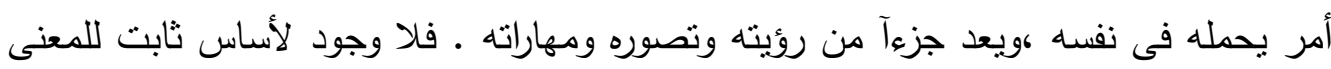

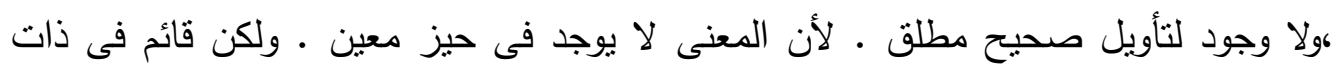

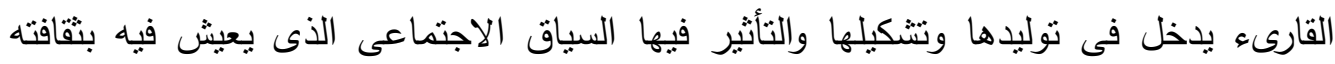

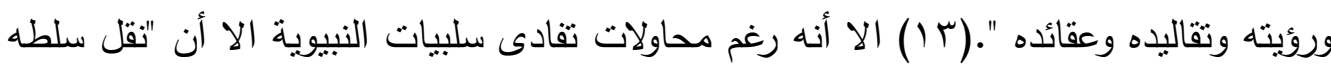

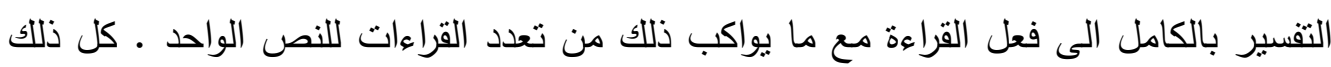

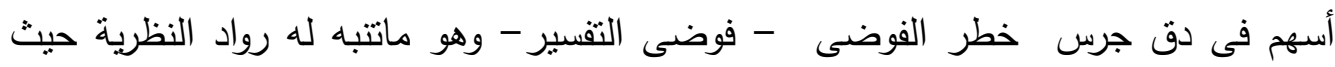


حاولوا تقديم ضوابط للتفسير والتى أسماها البعض أفق التوقعات بمعنى ماذا ينوقع القارىء أن

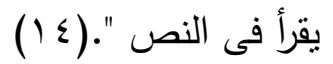

"ان تعدد المناهج النقدية أدت الىى بروز اتجاهات ومشاريع يلغى بعضها البعض الآخر

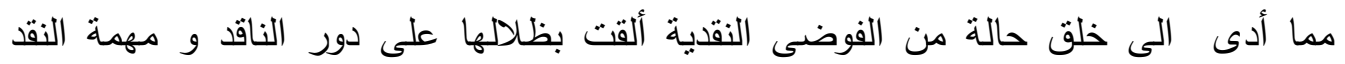

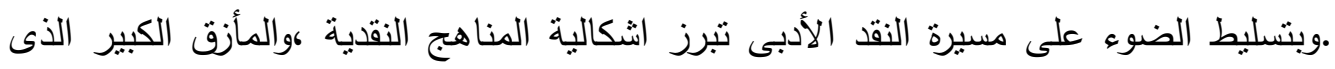

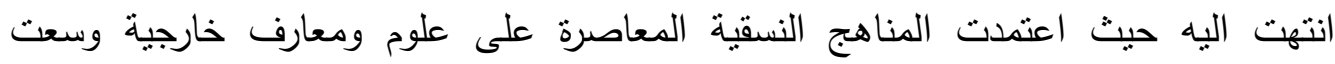

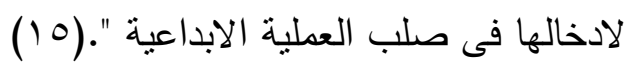

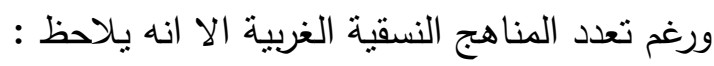

*تأسيس المناهج النسقية على أسس النظريات العلمية وهو مالا ينسق مع الطبيعة الفنية

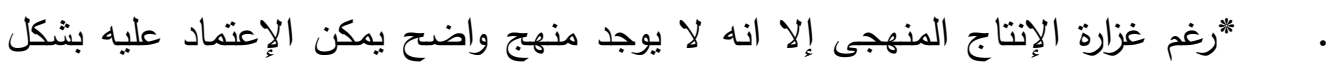
نهائى يصل الى أعماق العمل الفنى بشكل كامل.

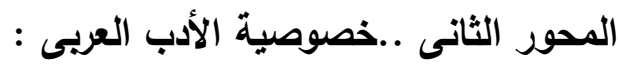
"ظهر النقد الأدبى عند العرب منذ العصر الجاهلى فى شكل أحكام انطباعية منلما نجد

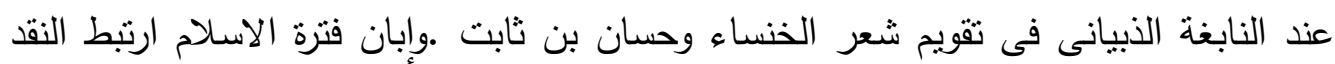

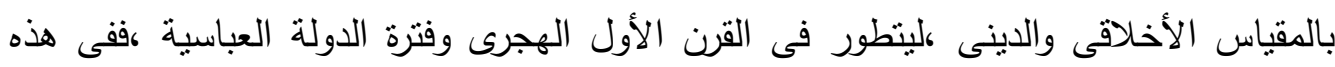

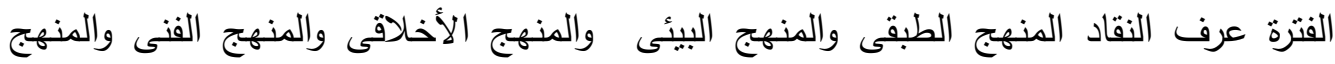

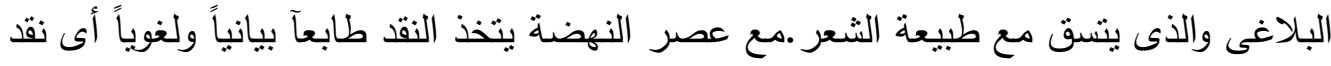

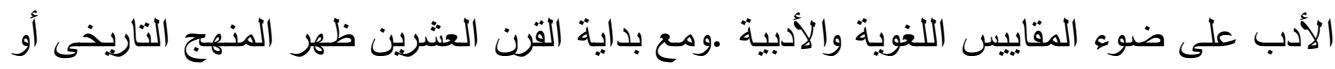

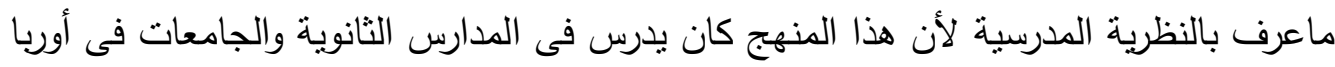

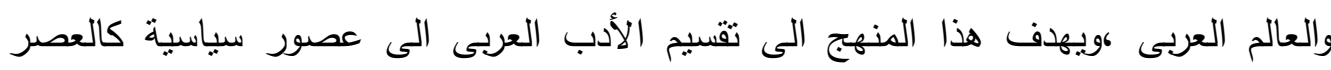

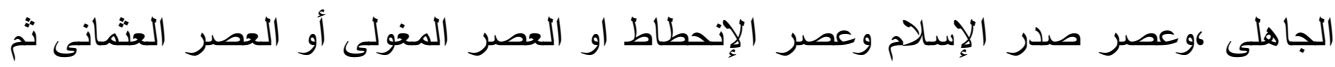

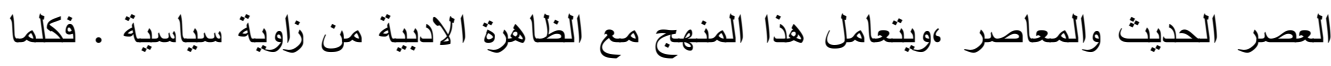

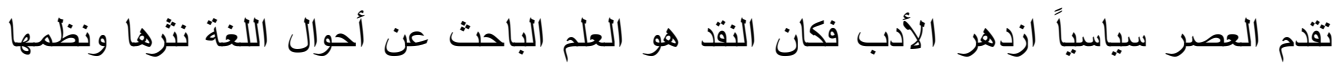

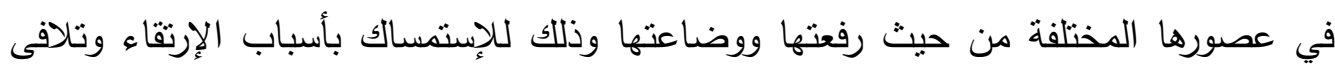

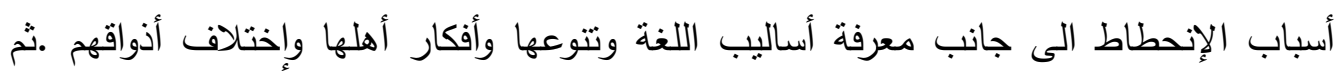

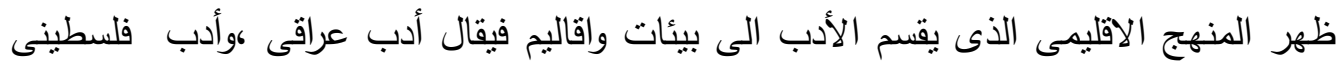

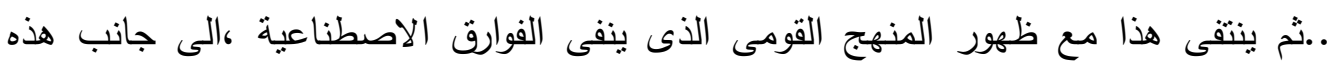

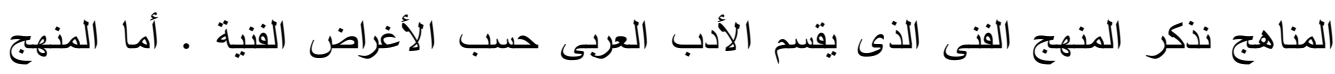

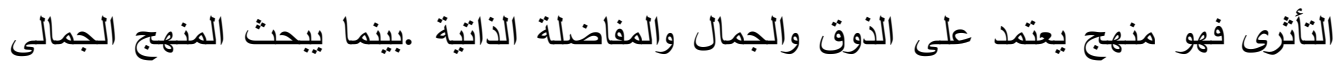


عن مقومات الجمال فى النص الأدبى من خلال عدة مفاهيم كالمتعة والروعة والتتاسب والتوازى

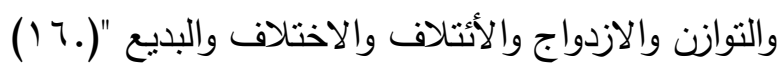
"لاثك فى أن العرب من الثعوب التى مارست نقد الثعرأو نقد الكلام قبل ظهور

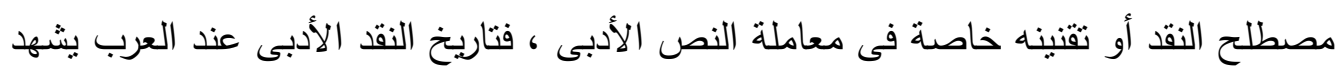

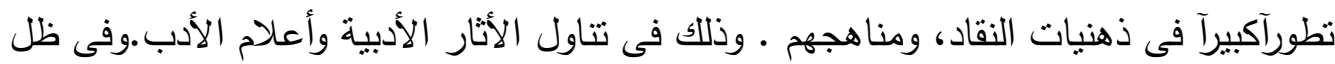

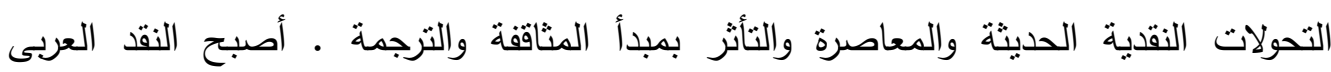

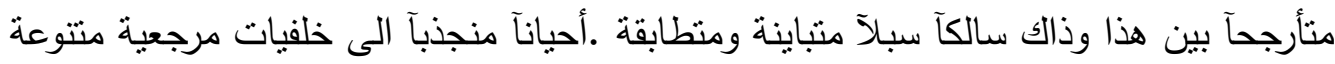

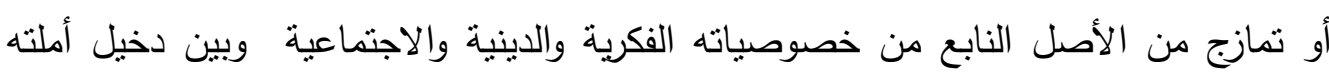

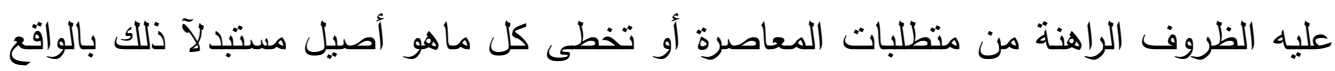
(lv)." الحضارى الجديد

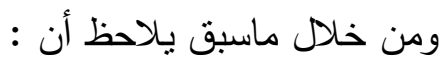
نظرآ لاختلاف المنابع الثقافية والحضارية والعلمية التى أنتجت المناهج النقاية الغربية النابة فانه

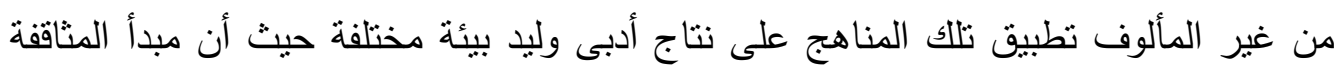

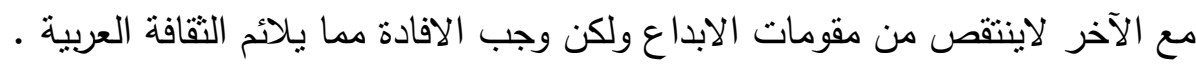

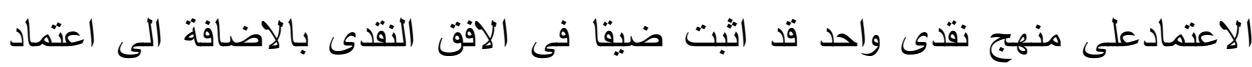

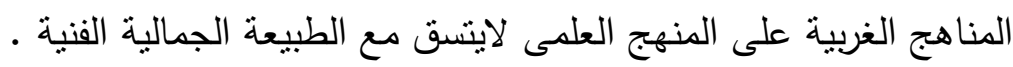

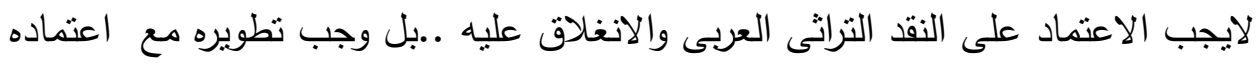
منبعآ للتجديد. وللخروج من تلك الاثكاليات النقدية وحلاً لهذا المأزق النقدى كان اتجاه بعض النقاد

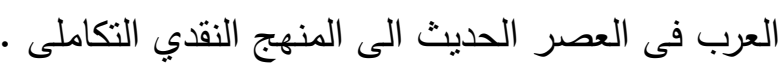

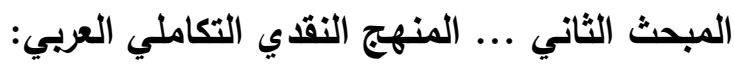
تعد المناهج النقدية وسائل وأدوات مساعدة على سبر أفئ أغوار الظاهرة الأدبية وليست غاية

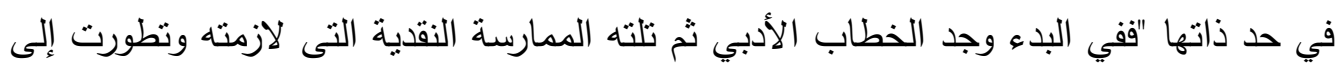

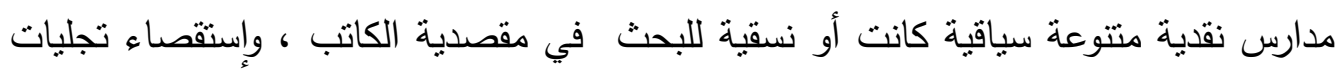

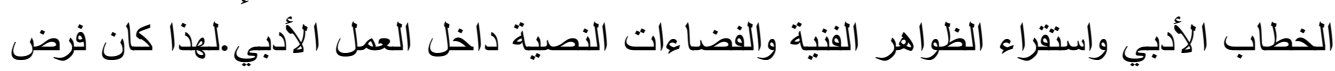

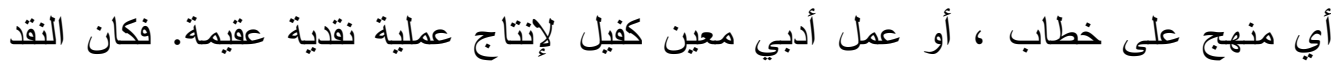

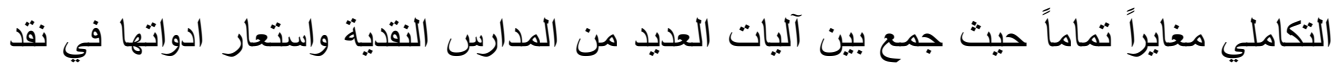

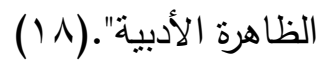
" والمنهج التكاملي هو منهج يأخذ من كل منهج مايراه معيناً على إصدار أحكام منكاملة

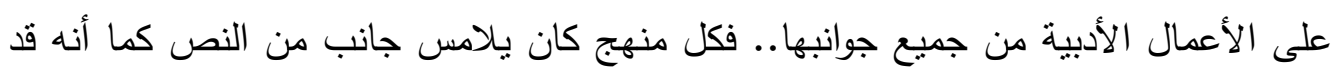


ثبت عدم قدرة أي منهج بمفرده على دراسة النص دراسة كافية - وهو ما اتضح من الصراعات

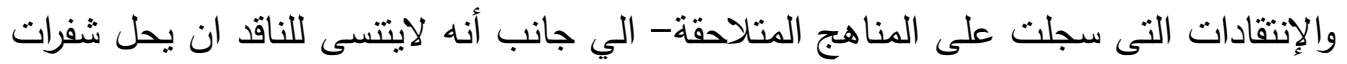
العمل الأدبي العربي بأدوات منهجية غريبة ظهرت من فلسفات وفي مجتمعات مغايرة". (9 (19)

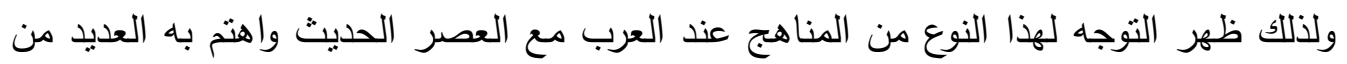

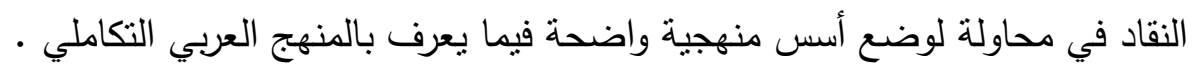

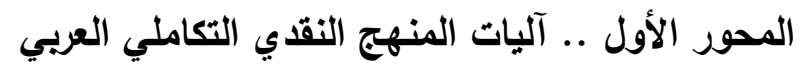

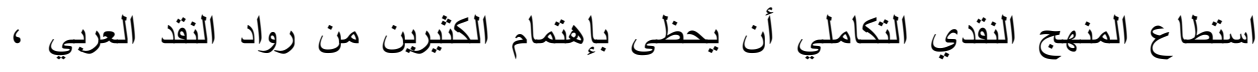

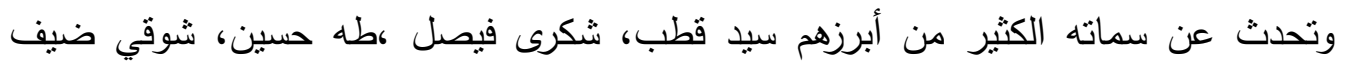
،ابراهيم عبد الرحمن، نعيم اليافي ....وغيرهم.

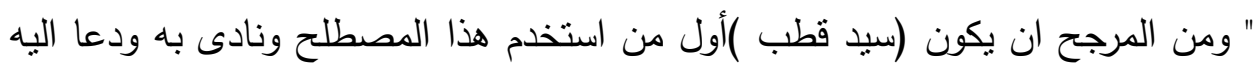

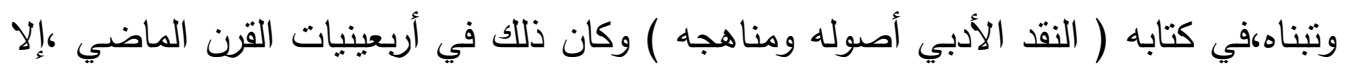

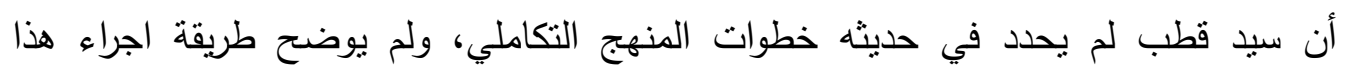
التكامل.

ثم يطالعنا (شكري فيصل )بعد سنتين من دعوة( سيد قطب) حين قدم أطروحته لدرجة

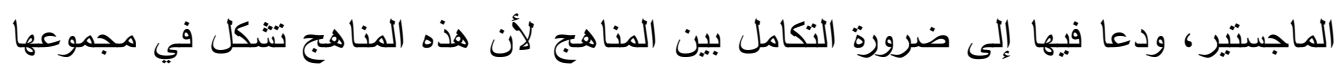

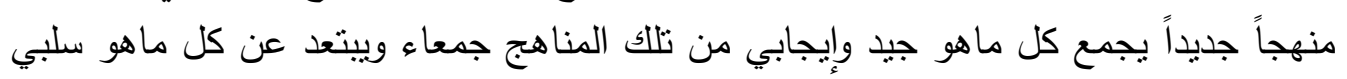
فيما أسماه المنهج التركيبي. إن التتبع التاريخي لأصول مصطلح التكاملية في النقد العربي الحديث لمعرفة السباقين

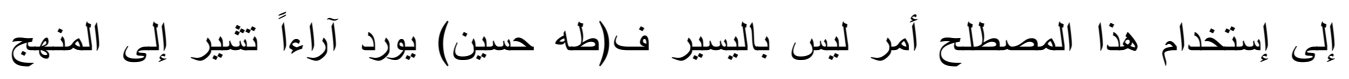

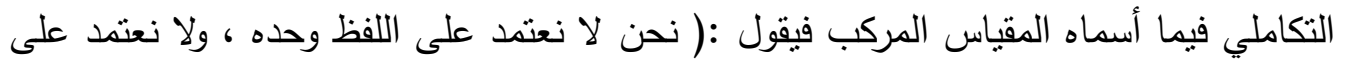

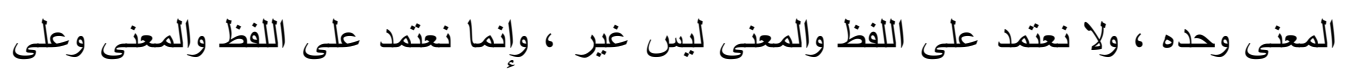

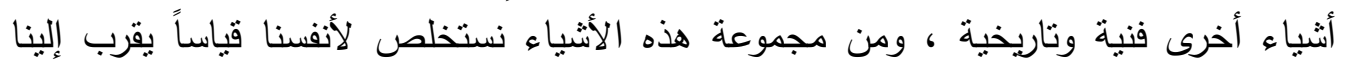

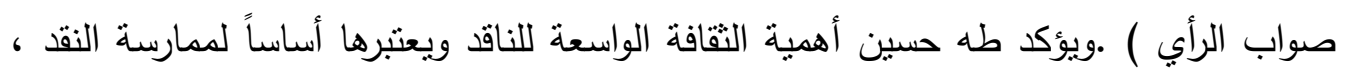

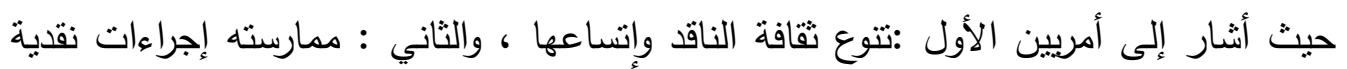

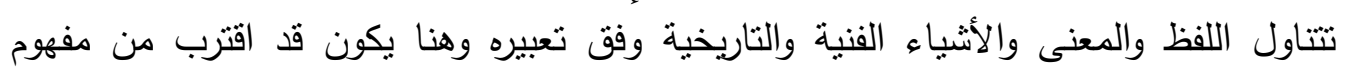

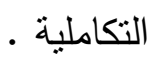

وفي السبعينات والثمانينات ظهرت دراسات كثيرة تتاولت المنهج التكاملي أو اقتربت منه،

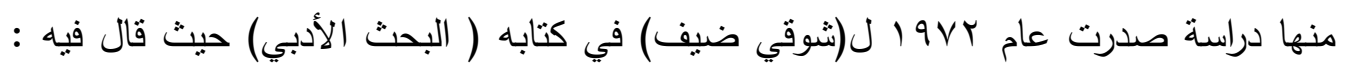

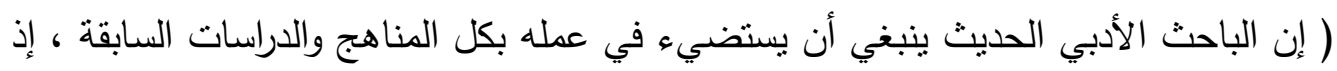

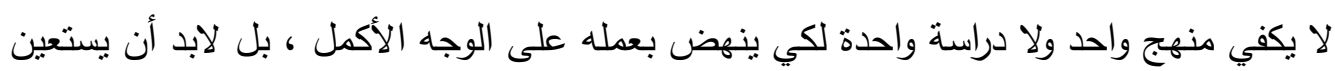


بها جميعاً ، فلا بد أن يتحول عقل الباحث إلى مايشبه مرآة تعكس أضواء كل تللك

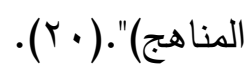

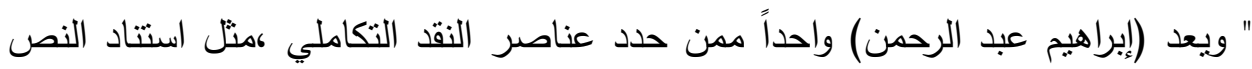
الى الواقع الذاتي والإجتماعي والطبيعي وانفتاحه على أثنياء أخرى ومن ثم إعادة إنداء تشكيلة فنباً،

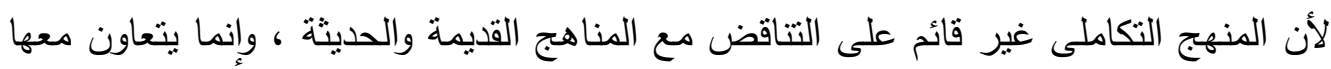

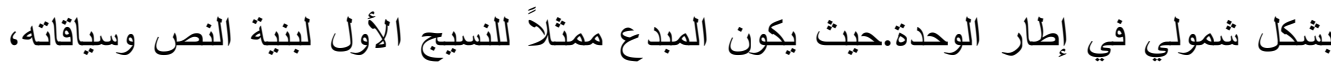

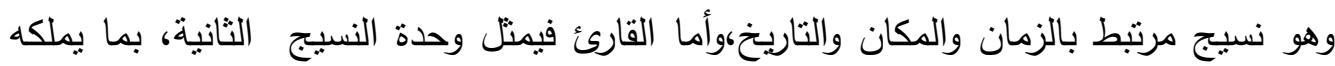

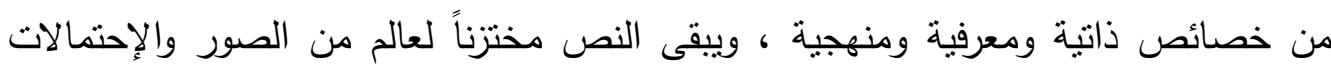

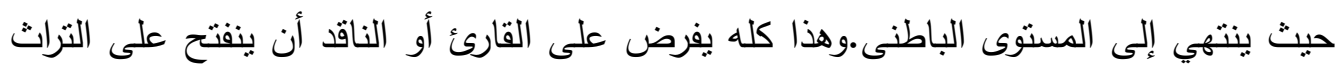

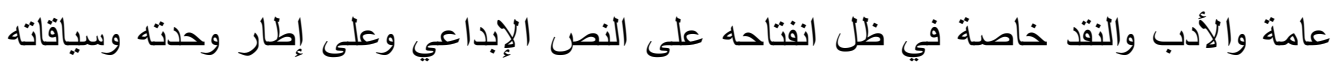

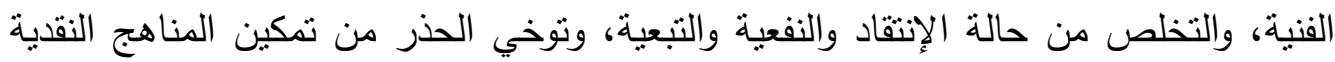

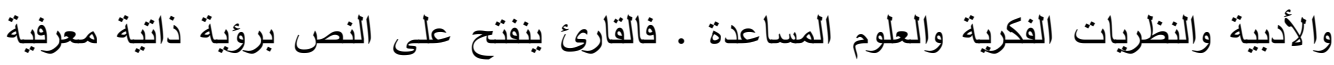

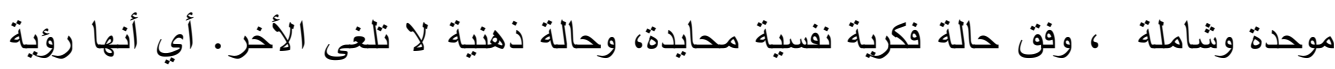

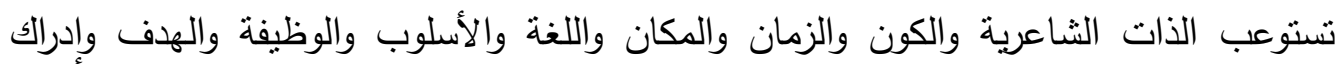

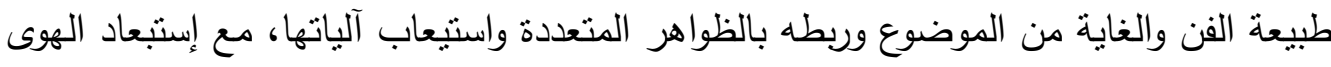

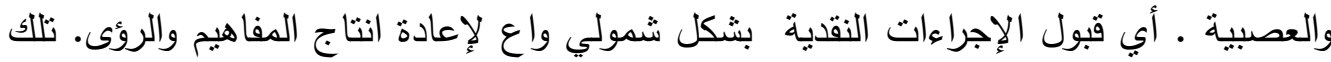

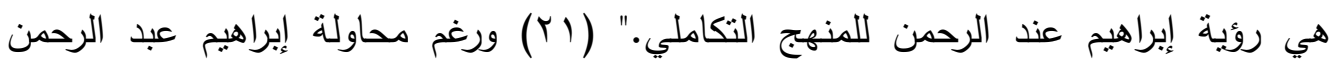

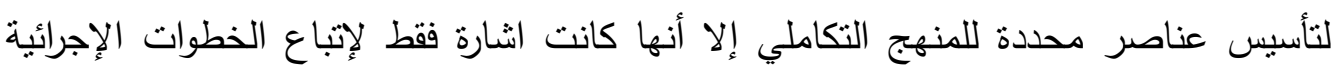
للمناهج الأخرى أثناء محاولة دمجها ، وذللك دون أن بحدد النتيجة المنهجية إجرائباً.

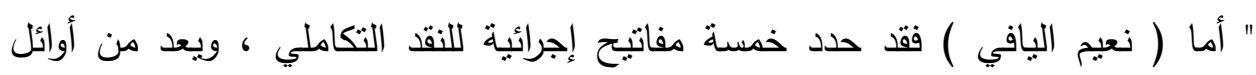

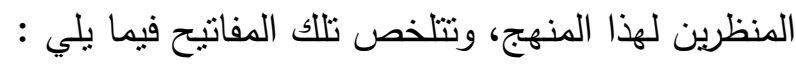

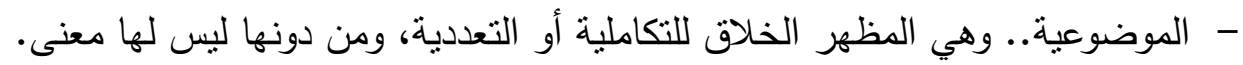

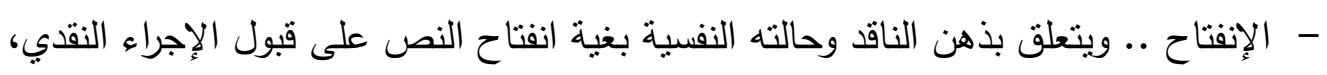

$$
\text { وانفتاح الناقد نفسه على قبول مختلف التقنيات النقدية. }
$$

- الإنتقائية ..هي ضريبة الموسوعية حين تكون ذات معرفة موسوعية فلابد أن تتنقي باجادة. - - - - - - - - - -

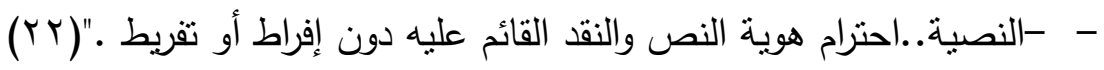

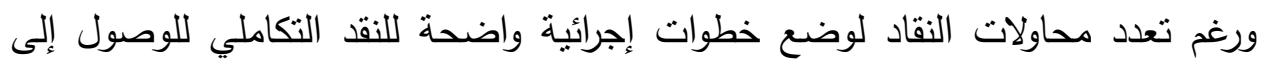
صيغة نظرية محددة -حيث كتب في ذلك أحمد كمال زكي وعبد المنعم خفاجى وجورج

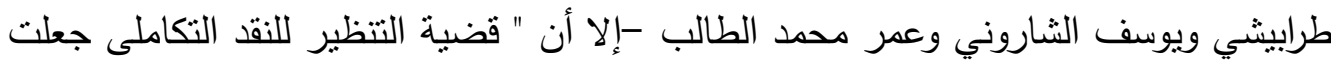


آساليب النقاد منباينة أثناء الشروع لوضع منهج نقدي تكاملي للظاهرة الأدبية (سواء شعراً أو

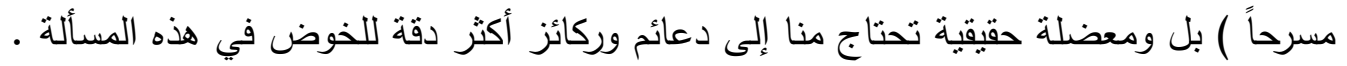

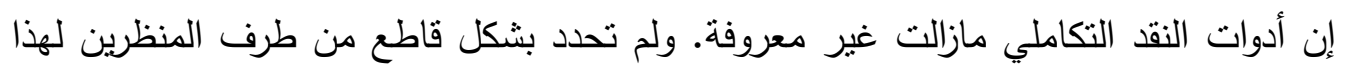

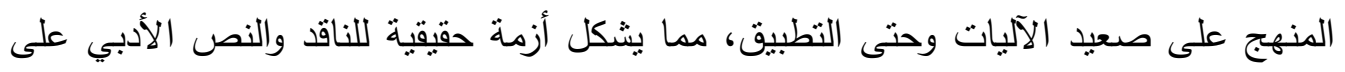

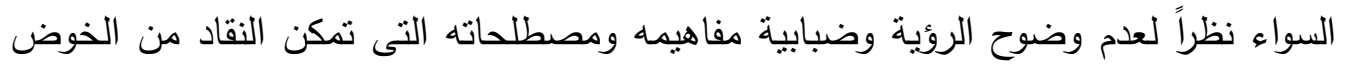

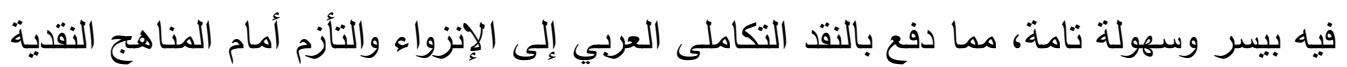

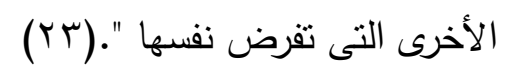

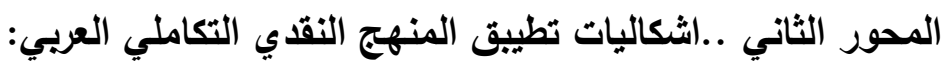

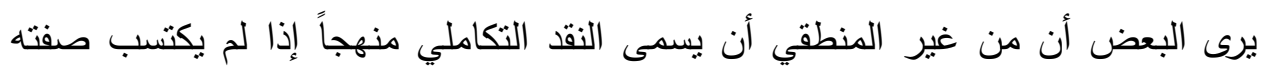

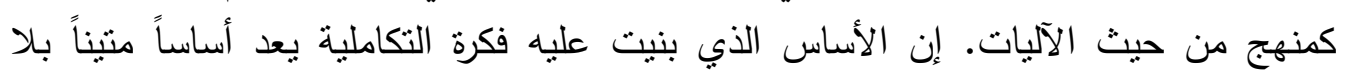

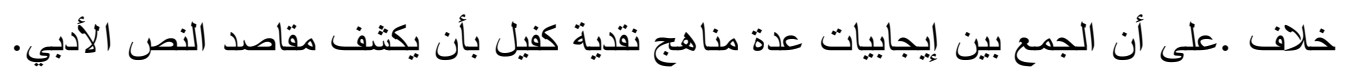

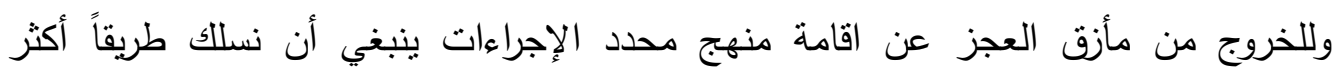

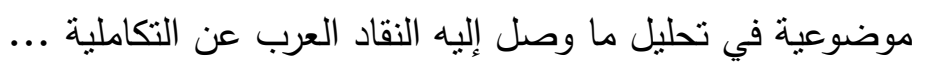

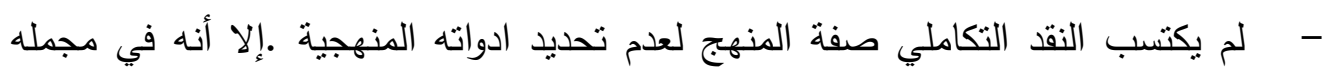

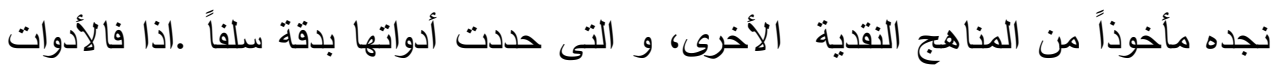

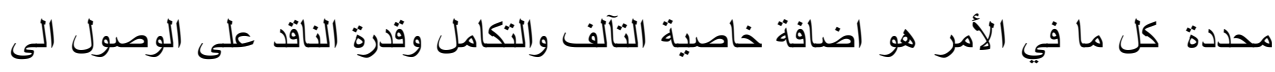
أعماق النص الأدبي من خلال إختيار مايعنيه على تحقيق هذا الهدف لوبذألك الكية تتنفي نسبياً

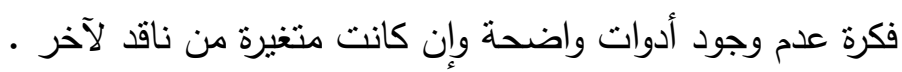

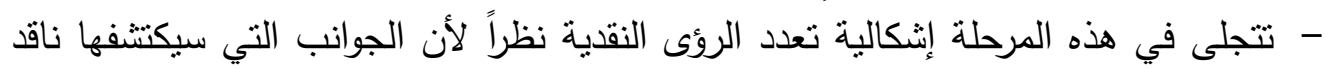

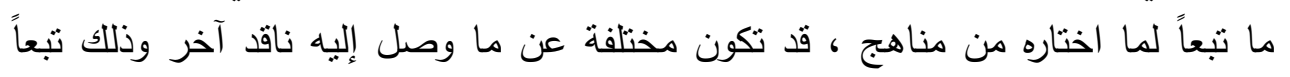

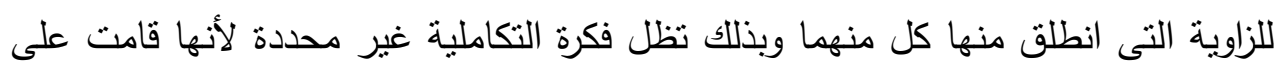

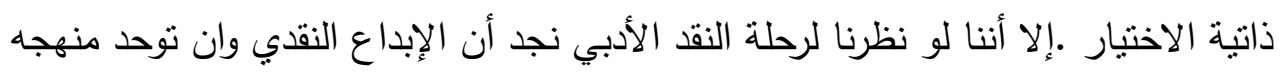

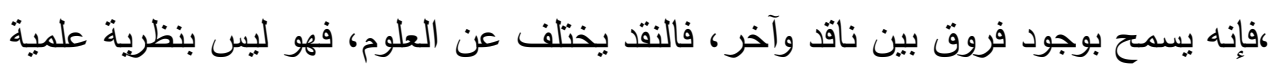

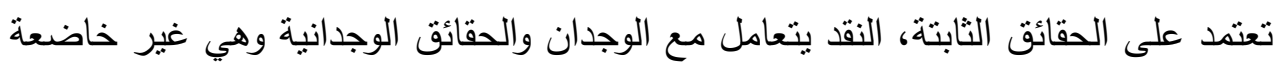

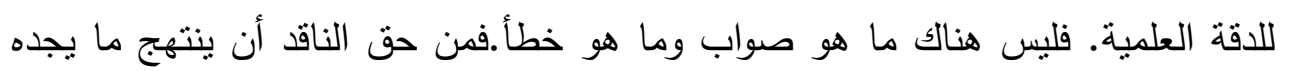
معيناً على إصدار أحكام ثقترب من الكمال. - وبذلك فنحن بصدد تساؤل حول علمية المناهج النقدية -وقد ذكرنا سلفاً أن المناهج الغربية

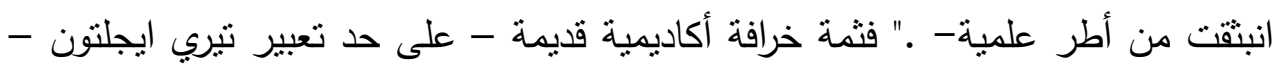

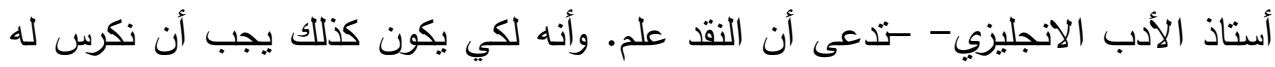

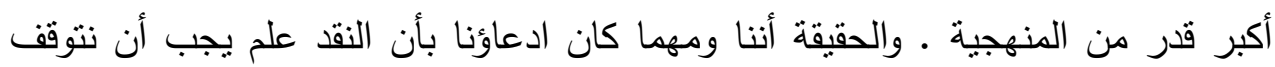


عند إمكانية أن يكون المنهج النقدي هو سببب علمية النقد. إن اللغة العلمية لغة نفعية

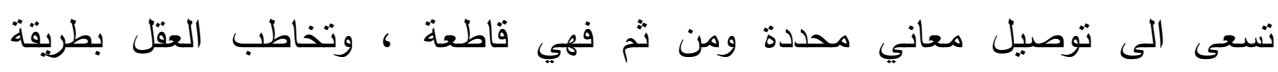

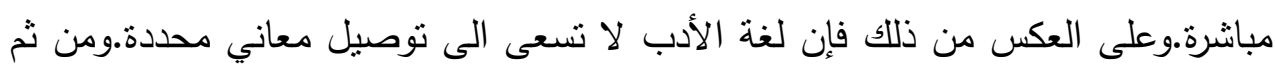

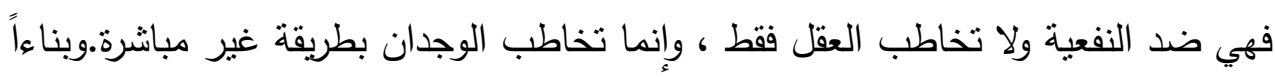

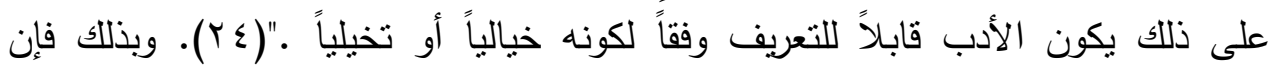
إخضاع النقد الأدبي للنسق العلمي محدد الأدوات والمعادلات بيتافى تماماً مع التأثثرات

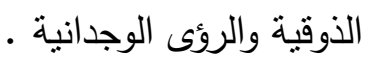

- - وبذلك تتمركز قضية التكاملية في يد الناقد حتى وان اختلف كل ناقد عن الآخر في زاوية

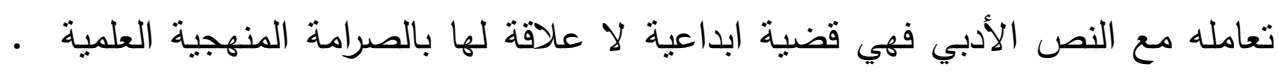

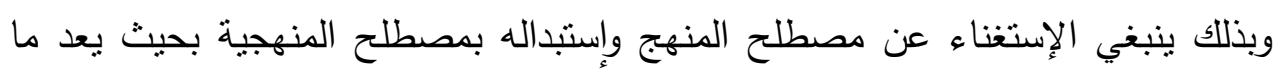

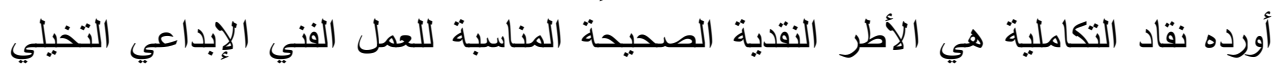

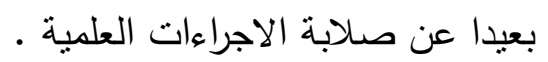

وتعد منهجية الناقد التكاملي والتي كتب فيها سيد قطب التب هي الأكثر وضوحاً وتفصيلاً وشمولية، حيث أنها جمعت بين كل ما أورده نقاد التكاملية مبرى سيد قطب أندا أنه "لكي نقرر

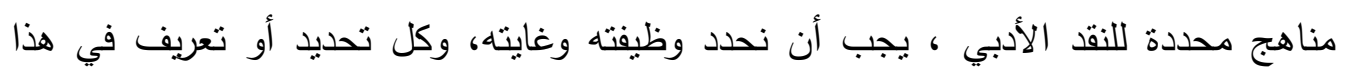

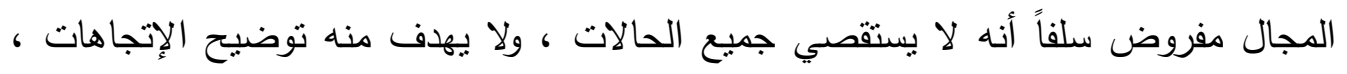

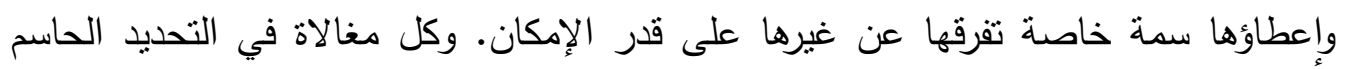

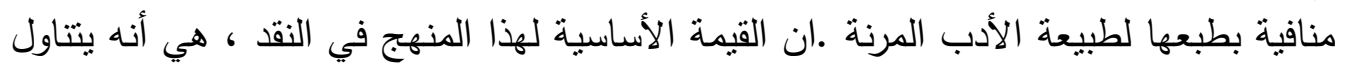

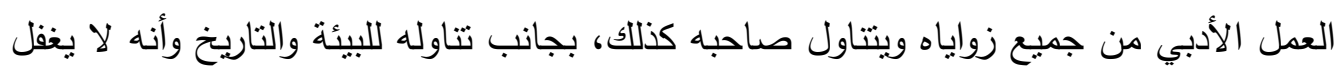
القيم الفنية الخالصة بحيث لا يغرقها في غمار البحوث التاريخية أو الدراسات النفسية.وبذلكاه ولكائل

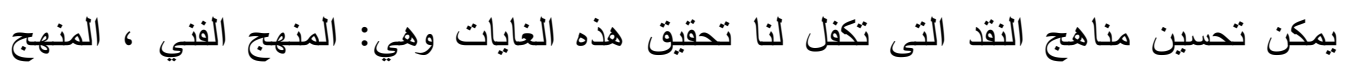

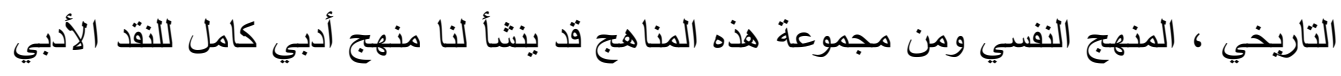

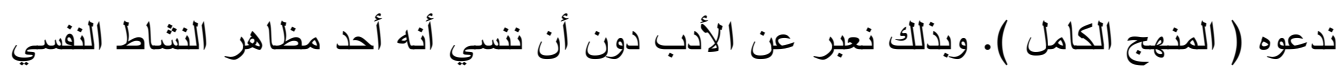

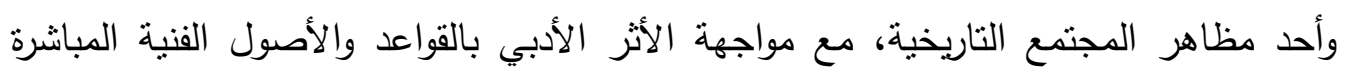

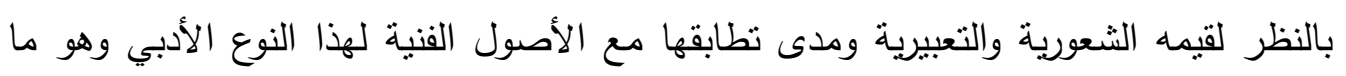

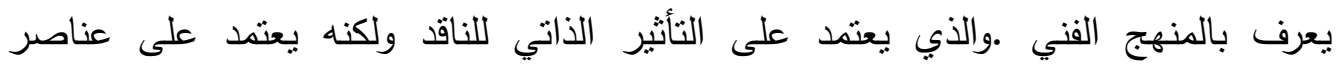

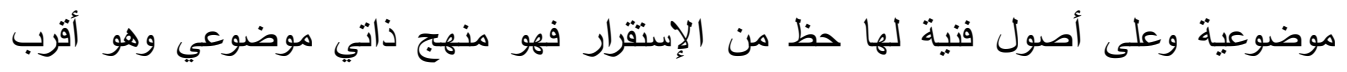

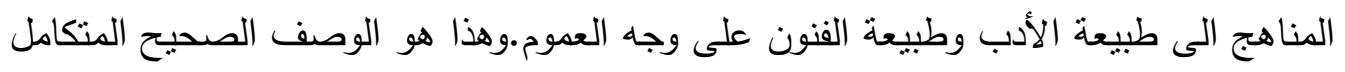

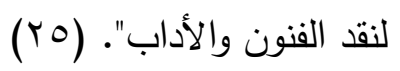


وكما حدد نعيم اليافي خمسة مفاتيح إجرائية للنقد التكاملي، فلقد حدد سيد قطب منهجية

الناقد ولقد ذكرها في أربعة نقاط : لإني

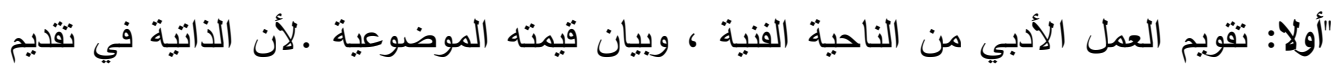

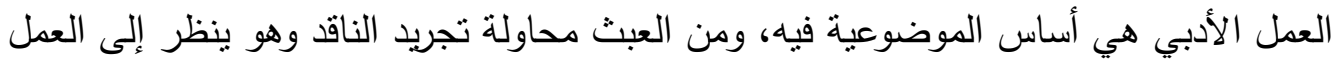

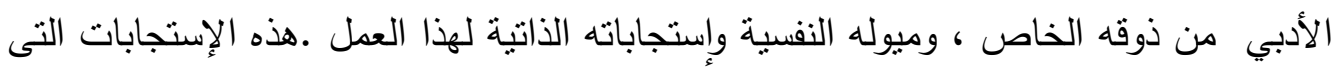

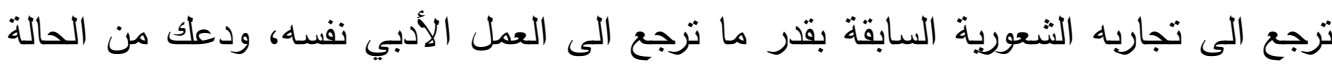

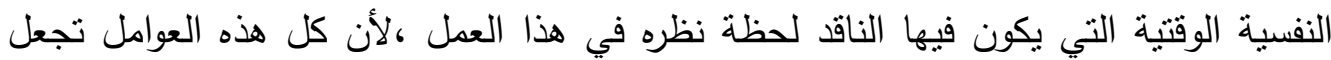
التقويم الفني للعمل الأدبي مسألة تفاعل بين هذا العمل وشعور الناقد ــ ـوهذا ما يسمونه الذانية

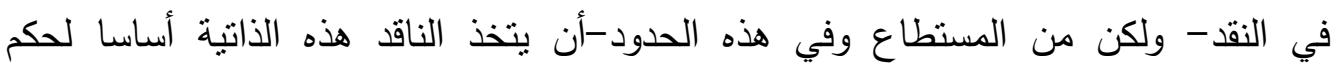

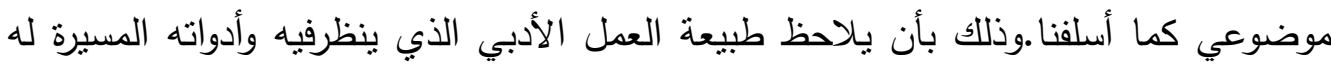

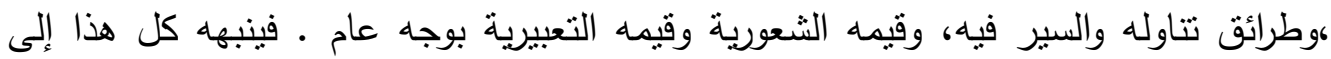

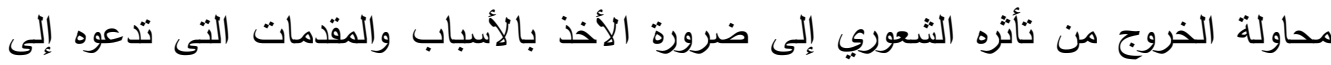

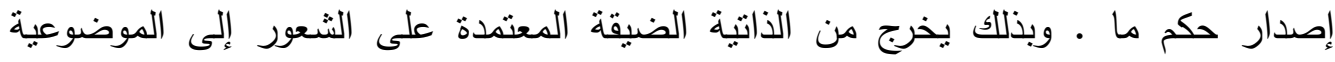

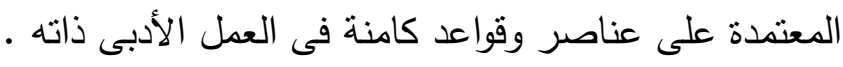

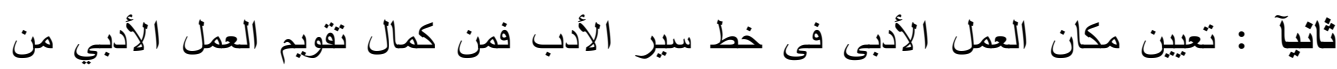

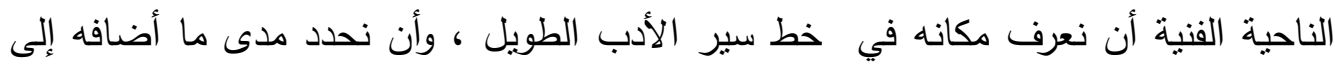

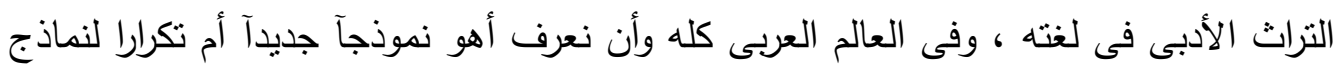

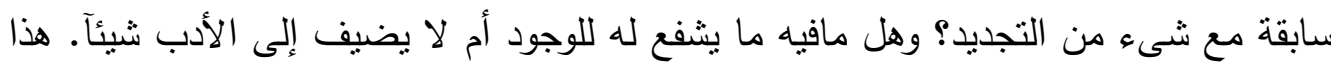

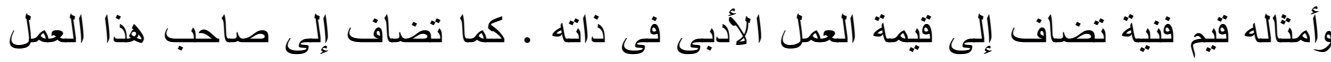

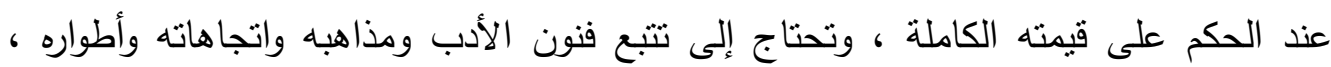

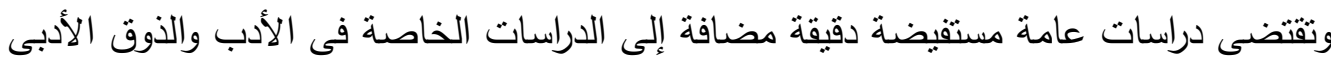
الخاص والقيم الموضوعية للعمل الأدبى . ثالثآ : تحديد مدى نأثر العمل الأدبى بالمحيط ومدى تأثثيره فيه و وهذه ناحية من نواحى التقويم

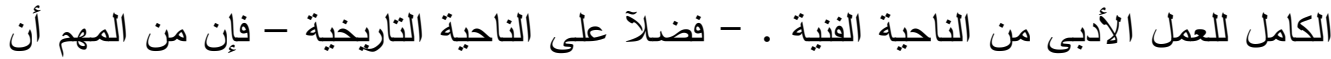

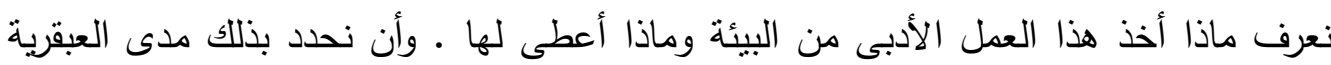

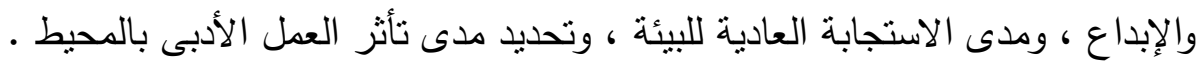

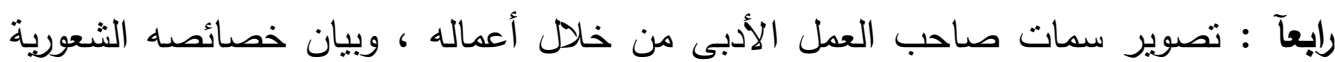

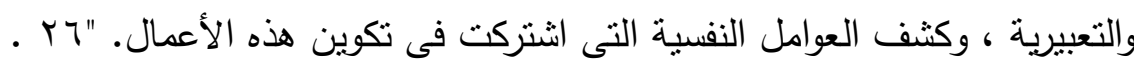

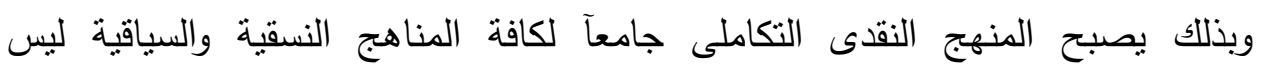
بالاعتماد على خطوات علمية لا تتتاسب وطبيعة الفن وإنما تعتمد على ذات إنسانية متمثلة فى 
الناقد الأدبى لأنه فى الأصل يتعامل مع منتج فنى ابداعى إنسانى ـ ويتجلى لنا هنا إثكالية

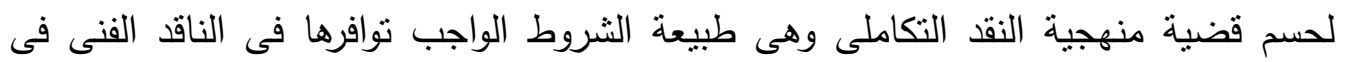
تقييمه للعمل الأدبي من خلال المنهجية التكاملية ـ ومن خلال تتبع ماكتب عن تللك المنهجية

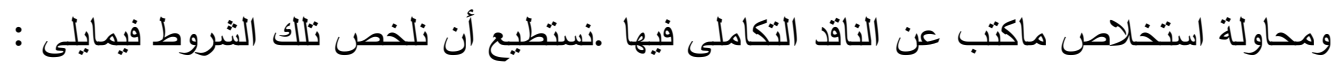

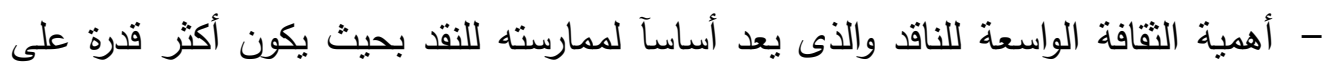

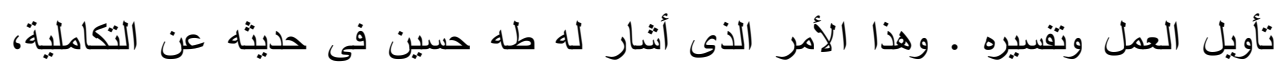

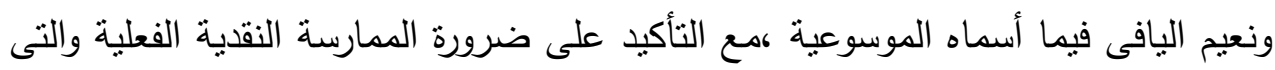
تمكن الناقد من سبرأغوار العمل الأدبى بحرفية أكبر .

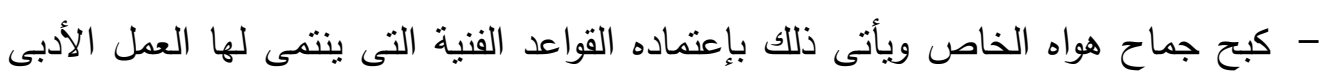

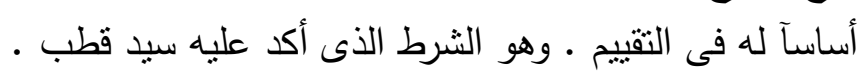
- الأخذ من كل منهج مايراه الناقد معينآعلى إصدار أحكام متكاملة ، وهوما يتطلب المعام المعرفة

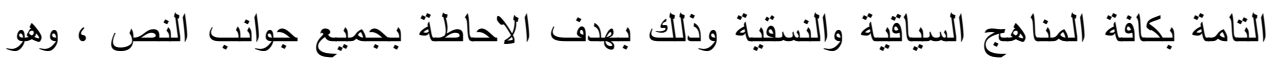

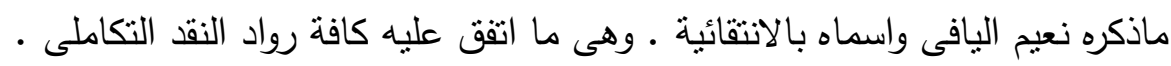

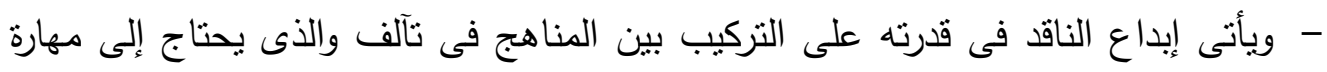

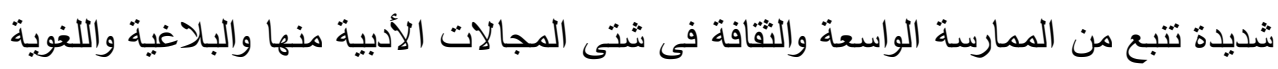

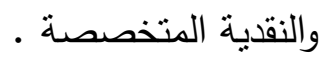
- وفى النهاية فإن المتلقى عليه أن يعى أن النقد ليس فيها صواب كامل أو خطأ كامل ـ إنما

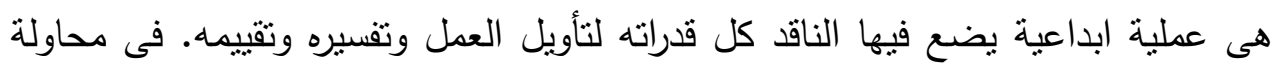
لاثراء الساحة الفنية بكتابات نقدية تقيد فى تطور العملية الفنية ـ فالتقييم الذى يقوم به ولفيه

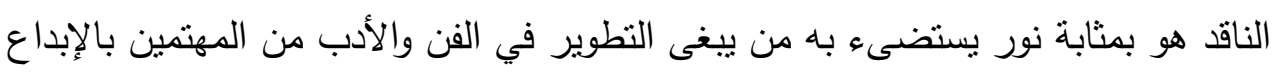

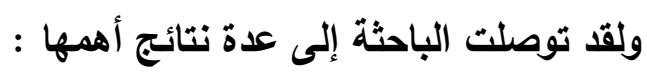

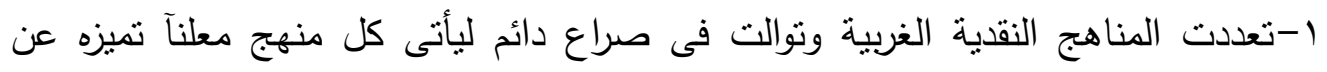

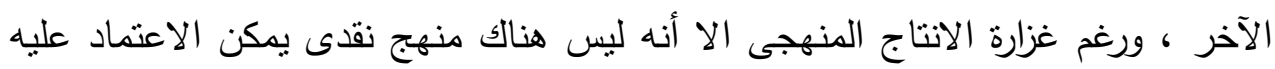

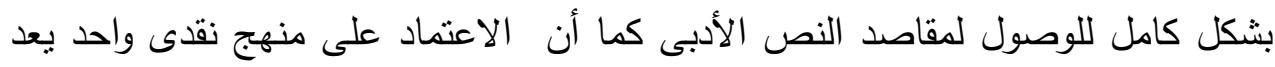

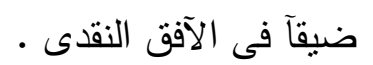
r-اعتمدت المناهج النقدية السياقية على الأطر الخارجية للنص الأدبى وتجاهلت الأبعاد

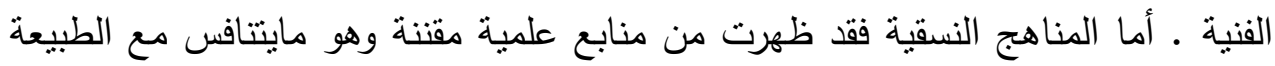
الفنية . r-ونظرآ لاختلاف المنابع التقافية والحضارية التى أنتجت المناهج النقدية الغربية فإن من

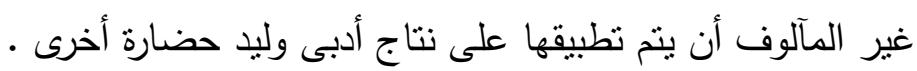


ع-إن المثاقةة لا تتص من مسنويات الابداع ولكن وجب الافادة من الايجابيات التى تتسق

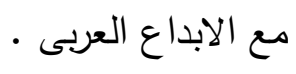

ه-اسنطاع المنهج النقدى التكاملى العربى أن يخرج بالعملية النقدية من فوضى المناهج

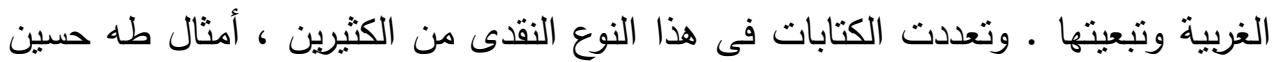

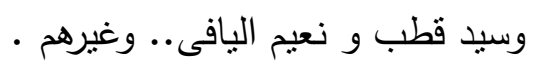

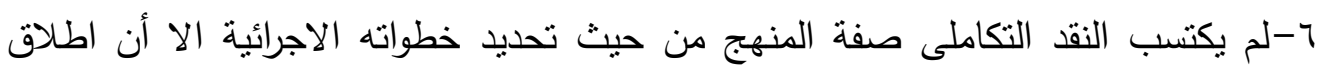

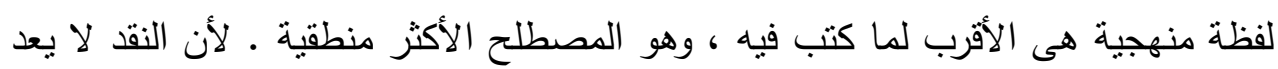
علمآ خاضعآ للاقة العلمية وليس فيه ماهو صواب أو خطأ وهو ما أكده ثنرى ايجلتون بأن

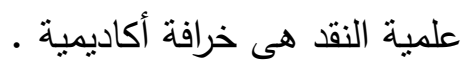

V-تمركز المنهجية التكاملية فى بد الناقد يوجب تأهله الثقافى والنقدى لاختبار مايجده معينآ

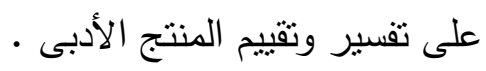

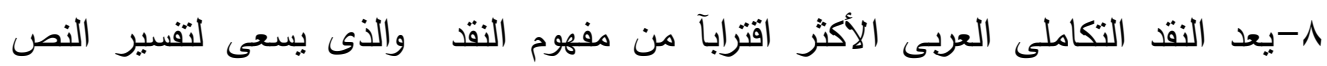

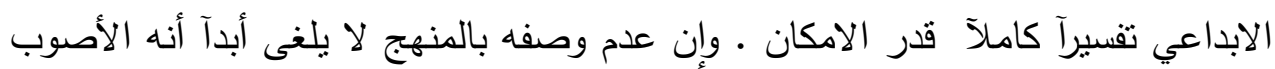

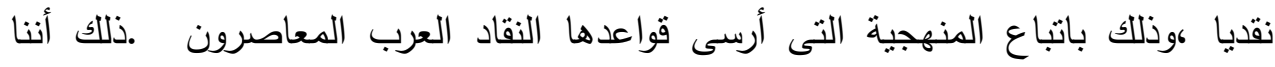

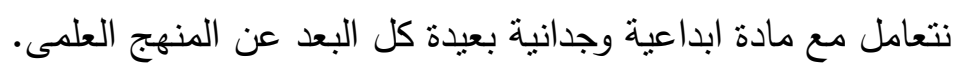

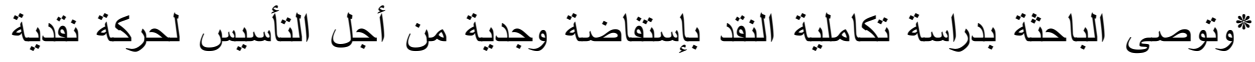
عربية حقيقية .فلقد ظهرت تلاك المنهجية من رحم الساحة النقدية العربية مستعينة بتراثها كوانفتاحها على الغرب فى إطار التعامل مع الابداع العربى • وإن عدم الاعتراف به كمنهج -

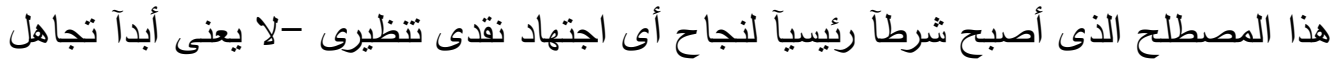

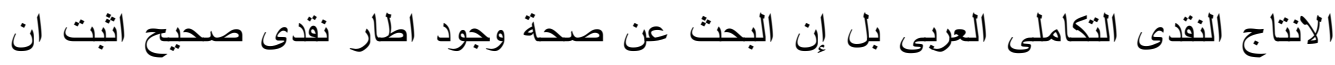

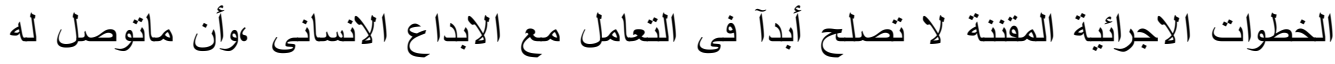
روادنا العرب فيما يخص تكاملية النقد ،والأسس المنهجية التى وضعوها هى ما ينبعى الألى الاهنمام

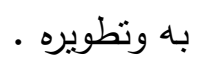
ولاأغفل أبدآ أن هناك ما ساعد على تجاهل هذا النوع النقدى ،وهو قلة اهتمام النقاد

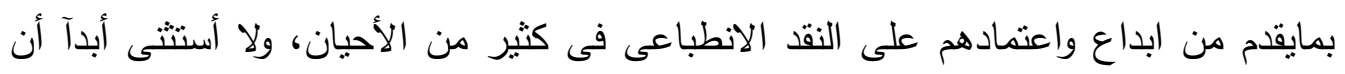

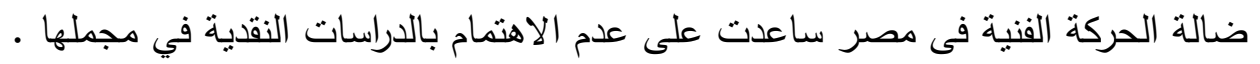




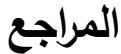

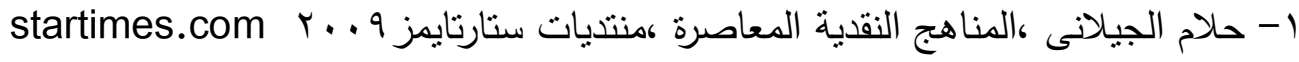

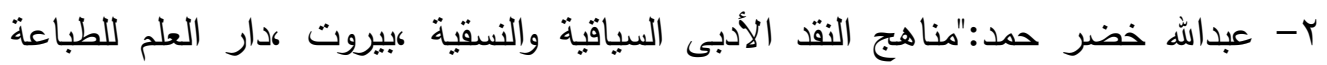

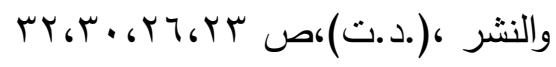

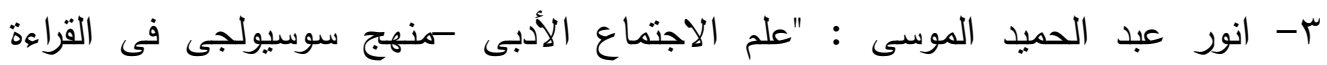

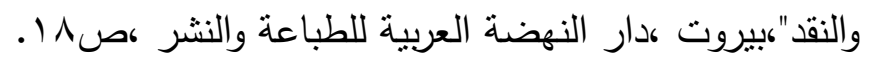

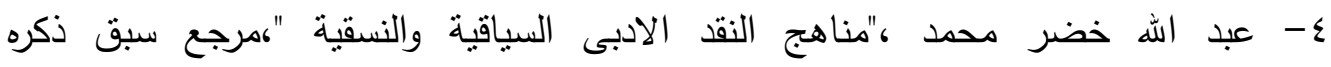

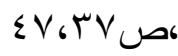

0- ابراهيم فضل اله :"علم النفس الأدبى مع نصوص تطبيقية"،بيروت،دار الفارابى للنشر

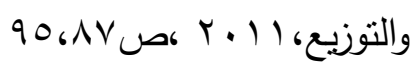

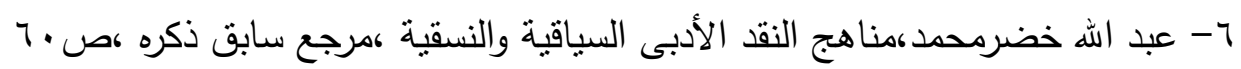

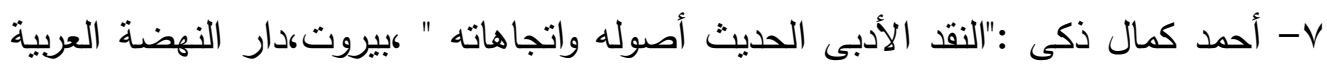

$$
\text { rVAص(91)، }
$$

1-حلام الجيلانى ،المناهج النقدية المعاصرة ،موقع سبق ذكره.

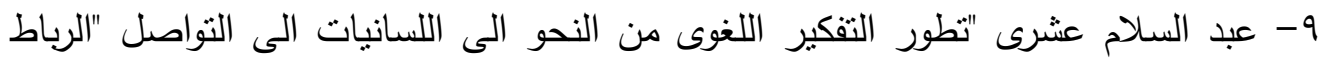

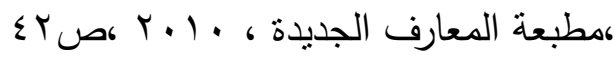

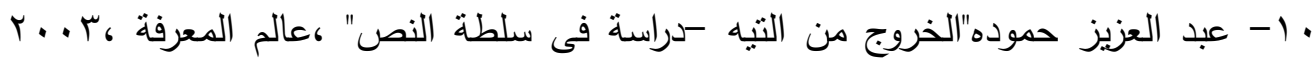

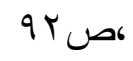

11 - فائق مصطفى عبد الرضى على"فى النقد الأدبى -منطلقات وتطبيقات " الموصل

$$
\text { 19001919، }
$$

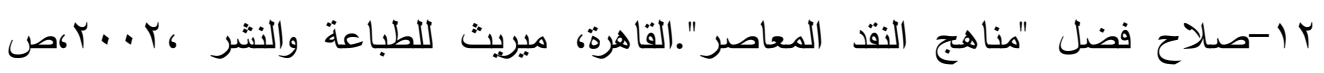

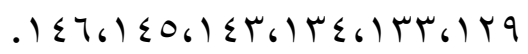

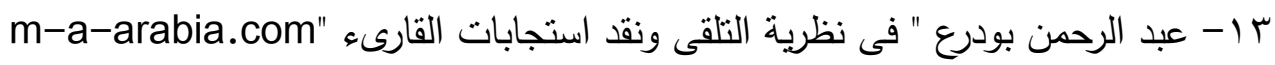

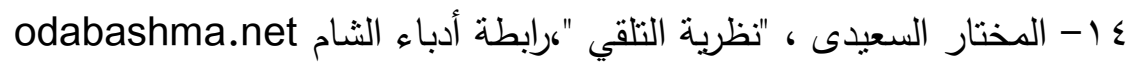

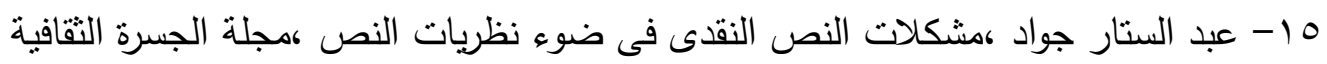

\section{aljasra.org}

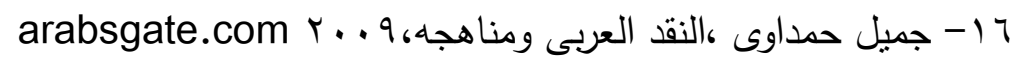
V V Vمد الأمين شيخة،النقد العربى المعاصر وروافده ،المدونة الأكاديمية للأدب والنقد cheikha.blogspot.comr.11، 
(1) (1) عامر رضا : " النقد التكاملي واشكالية تطبيقه على الدراسات الأدبية " ، أصوات الثمال

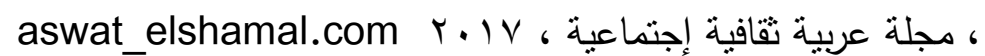

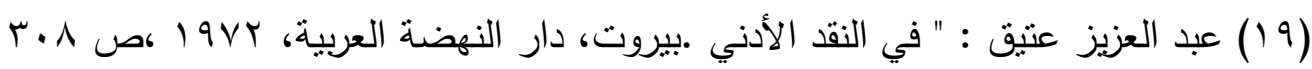

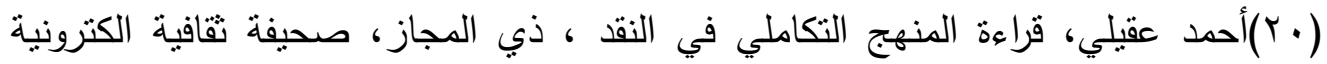

Zelmajaz.com

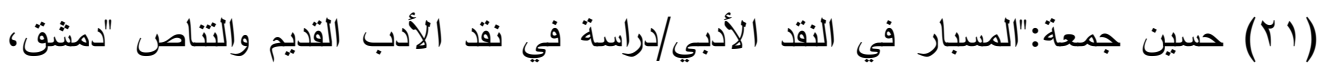

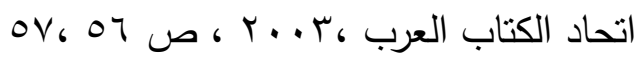

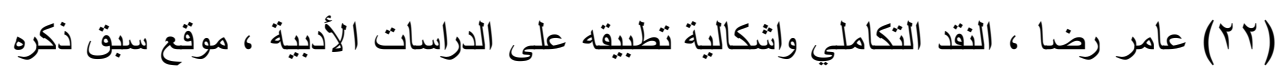
(YT)

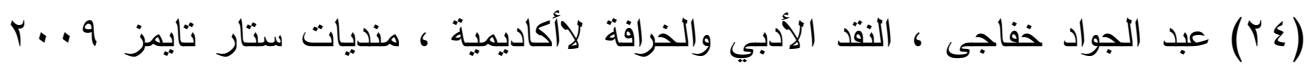

\section{Startimes.com}

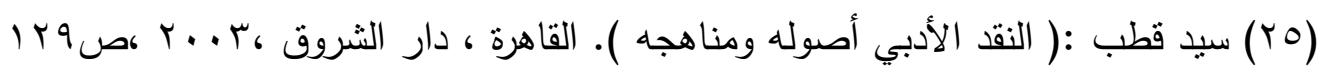
1 r1, ror,

דr- سيد قطب " المرجع نفسه " ، ص 